- A New Path: Undergraduate Libraries at United States and Canadian Universities, 1949-1987, by Roland Person (183 pages, April 1988), is a comprehensive description and analysis of the role of undergraduate libraries in the modern university and the goals upon which they were founded and continue to operate. Person, assistant undergraduate librarian at Southern Illinois University, presents data on why some undergraduate libraries have failed and why others have succeeded. Copies may be ordered for $\$ 29.95$ from Greenwood Press, 88 Post Road West, Box 5007, Westport, CT 06881. ISBN 0-313-25303-X.

- United States Government Publications Catalogs, by Steven D. Zink (312 pages, 2d ed., 1988), contains more than 370 catalogs, bibliographies, and publications lists that may prove useful in locating documents produced by federal governmental agencies. New to this edition are a title index, an

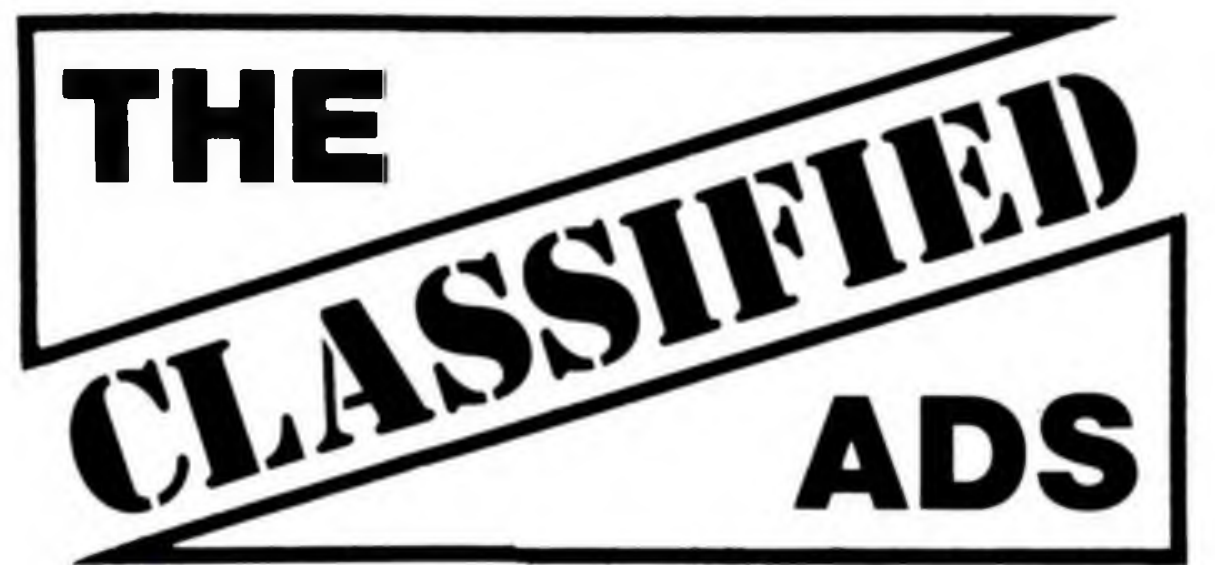

Deadlines: Orders for regular classified advertisements mus reach the ACRL office on or before the second of the month preceding publication of the issue (e.g. September 2 for the October issue) If the second falls on a weekend, the deadline is the following Monday. Late job listings will be accepted on a space-available basis af ter the second of the month.

Rates: Classified advertisements are $\$ 5.00$ per line for ACRL members, $\$ 6.25$ for others. Late job notices are $\$ 12.00$ per line for members, $\$ 14.00$ for others. Organizations submitting ads will be charged according to their membership status.

Telephone: All telephone orders should be confirmed by a written order mailed to ACRL headquarters as soon as possible. Order should be accompanied by a typewritten copy of the ad to be used in proofreading. An additional $\$ 10$ will be charged for ads taken over the phone (except late job notices or display ads)

Guidelines: For ads which list an application deadline, that date must be no sooner than the 20th day of the month in which the notice appears (e.g.. October 20 for the October issue). All job announcements should include a salary figure. Job announcements will be edited to exclude discriminatory references. Applicants should be aware that the terms faculty rank and status vary in meaning among institutions.

JOBLINE: Call (312) 944-6795 for late-breaking job ads for academic and research library positions. A pre-recorded summary of positions listed with the service is revised weekly; each Friday a new tape includes all ads received by 1:00 p.m. the previous day. Each isting submitted will be carried on the recording for two weeks. The charge for each two-week listing is $\$ 30$ for ACRL members and $\$ 35$ for non-members.

Fast Job Listing Service: A special newsletter for those actively seeking positions. This service lists job postings received at ACRL headquarters four weeks before they appear in C\&RL News, as well as ads which, because of narrow deadlines, will not appear in C\&RL News. The cost of a six-month subscription is $\$ 10$ for ACRL members and $\$ 15$ for non-members.

Contact: Classified Advertising Dep't, ACRL, American Library Association, 50 E. Huron St., Chicago, IL 60611; (312) 944-6780.

\section{POSITIONS OPEN}

ACQUISITIONS LIBRARIAN to manage the activities of an eight person, automated (INNOVACQ) department responsible for ordering, receiving, binding and mending monographs and serials. The expanded subject index, and lengthier annotations. The emphasis is on currently available catalogs or serials; consequently no date is given indicating when particular items were first published. The cost is $\$ 20$, from the Special Libraries Association, 1700 Eighteenth St., N.W., Washington, DC 20009. ISBN 0-87111-335-X.

- Yearbook of American Universities and Colleges: Academic Year 1986-1987, edited by George Thomas Kurian (653 pages, May 1988), reviews the major topics in higher education for the past year. Of major interest are the essay on "Historically Black Colleges" by Reginald Wilson, a statistical section, and case summaries of major court decisions affecting colleges and universities in 1986 . The cost is $\$ 60$. Contact Garland Publishing, 136 Madison Ave., New York, NY 10016. ISBN 08240-7942-6.

library has a materials budget of 1.5 million, acquires $12,000+$ monographs per year through firm orders and approval plans and subscribes to 5,200 periodicals. Acquisitions Librarian reports to the Head of Collection Development. Required: ALA-accredited MLS experience supervising staff and managing projects, excellent communication and bibliographic skills and experience in or familiarity with acquisitions and binding processes. Minimum salary is $\$ 24,000$ for a 12 month appointment. Fringe benefits include 20 working days annual leave, tuition waiver, TIAA/CREF, life and fully paid family health insurance. Applications received by June 22, 1988, will receive first consideration. To apply send letter of application, resume and names of at least 3 references to: Joyce Rumery, Chair, Acquisi tions Librarian Search Committee, Raymond H. Fogler Library, University of Maine, Orono, ME 04469. The University of Maine is an Affirmative Action, Equal Opportunity Employer.

ARCHIVIST. Yale University. Beinecke Rare Book and Manuscrip Library. Five Year Term Appointment. Processes manuscript hold ings from the Beinecke's five collections. Qualifications: MLS degree from an ALA-accredited library school and/or M.A.. preferably in the humanities. Formal training in archival theory and practice. Strong knowledge of literature and history; broad general knowledge in the humanities. One to two years experience processing literary and historical manuscript materials. Familiarity with AACR2, LC and local authority control, and automated bibliographic and management in formation systems. Excellent reading knowledge of western Euro pean Ianguages; Italian, Spanish, and/or Latin preferred. Demonstrated ability to work effectively with others. Familiarity with RLIN/AMC and MARC formats for archives and manuscripts desirable. Application deadline: June 30, 1988. Salary commensurate with experience; $\$ 23,500$ minimum. Please send letter of application, resume, and the names of three references to: Maureen Sullivan, Head, Library Personnel, Yale University Library, Box 1603A Yale Station, New Haven, CT 06520. An EEO/AA employer.

ART AND DESIGN DEPARTMENTAL LIBRARIAN, Southwes Missouri State University. 12 month position begins September. Sal ary dependant upon degrees and experience. Preferred qualifica tions: MLS and MA in Art History and experience working with visual materials or MLS and BA in Art History/MFA/BFA in studio and expe rience working with visual materials. Responsibilities include: all du ties necessary for operation of Slide Library (including supervision of student workers); library collection development (books and periodicals); possible adjunct appointment with Department of Library Science. Salary range: $\$ 22,000-\$ 26,000$. Further information available upon request. Include detailed letter of application, resume, official transcripts, 3 reference letters. Screening begins June 19, 1988 continuing until position filled. Slide Library Search Committee, De partment of Art \& Design, Southwest Missouri State University, Springfield, MO 65804-0089. AA/EOE

ASSISTANT CATALOGING LIBRARIAN, South Dakota State University. Open August 1, 1988. Faculty position reporting to the Head of Cataloging with particular responsibility for cataloging special col 
lections on OCLC and related duties in completing online catalog database. Initially annual term appointment for up to three years with possible reassignment at project end. Will also assist in regular cataloging department activities and the revision of work performed by paraprofessionals and students. Qualifications: ALA-accredited $M L S$, effective interpersonal relationship skills, working knowledge of OCLC, AACR2, Dewey and LC classifications; demonstrated ability to communicate effectively. Desired qualifications: two years experience in general cataloging or specialized cataloging of non-print materials and knowledge of a modern foreign language. Salary range $\$ 18,500-\$ 20,000$ depending on qualifications. Twelve month term appointments with standard benefits. Application deadline is June 30, 1988, or until suitable applicant is hired. Send letter of application, resume and have transcripts and three recent letters of recommendation (which describe applicant's job-related qualifications) sent to: B.J. Kim, H.M. Briggs Library, Box 2115, South Dakota State University, Brookings, SD 57007. An AA/EEO employer

ASSISTANT DEAN FOR PUBLIC SERVICES, Montana State University Libraries. Tenure track, FY position at rank of Assistant or Associate Professor. Starts 9/1/88. Coordinates public service departments, including Reference, Circulation, Government Documents, Special Collections/Archives, and Creative Arts Branch Library; participates in planning and implementation of policies of University Libraries; provides leadership for 12 librarians and 25 support staff. Required: Master's degree from ALA-accredited program and subject master's or doctorate. Minimum five years successful and progressively responsible library experience in public services, including supervision of professional librarians and administration. Demonstrated excellence in administrative, interpersonal and communication skills. Preferred: Experience in an academic library. Must be willing to undertake research, publication and university profes- sional service required for faculty rank and tenure. Salary $\$ 38,000$. 21 days vacation; TIAA/CREF or state retirement plan; deferred compensation packages; life, health and dental insurance; university wellness program. Send letter of application addressing above qualifications plus complete vita, and names, addresses and phone numbers of five recent professional references to: Assistant Dean's Search Committee, Dean's Office, MSU Libraries, Montana State University, Bozeman, MT 59717-0022; (406) 994-3119. Screening will begin July 8,1988 , and continue until suitable candidate is hired. MSU is an AA/EO Employer.

ASSISTANT DIRECTOR FOR PUBLIC SERVICES. Dynamic, ur ban academic library seeks creative, energetic, flexible individual with strong commitment to public services, to manage General Library Public Services Division. Directs eight librarians who manage Access Services, Conservatory of Music Library, Government Documents/Microforms, Reference; and two branches, Instructional Materials Center (Education School) and Truman Campus Library (Independence, MO). Programs include Bibliographic Instruction, fee-based Community Information Program, Online Literature Searching, Interlibrary Loan, and Photocopy Services. Public Services librarians report to Assistant Director for Collection Development for collection development and faculty liaison responsibilities and to the Assistant Director for Public Services for all other activities Assistant Director for Public Services responsibilities also include planning and initiating efficient use of the division's resources, developing and promoting public services, participating in library-wide automation, planning, and decision-making. May be assigned collection, faculty liaison responsibilities. Reports to Associate Director and serves on Libraries Directors Group. Library automation includes wide PC access, WLN-based online catalog/circulation (LUMIN) linking four U of MO campuses, OCLC cataloging/ILL/re

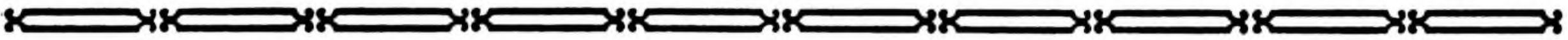

\section{LIBRARY SYSTEMS ANALYS}

The University of Southern California Libraries is seeking a Library Systems Analyst. Reports to Head of Bibliographic Information Services. Assists with technical management of Library's integrated automated system (GEAC), and user support. GEAC includes Acquisitions, Circulation, MARC Records Management and Public Online Catalog modules. Responsibilities include software support and analysis, preparation of program specifications, preparation and maintenance of system, procedural documentation, end user training, and support.

Qualifications and experience required: MLS from an ALA-accredited library school; knowledge and experience in systems analysis, computer hardware and software technologies, and the ability to work with the MARC format and its applications to automation. Must have excellent oral and written communication skills. Rank and salary negotiable depending on experience and qualifications. Minimum salary: Librarian I, $\$ 27,606$, plus benefits. Position open July 1,1988 , and will remain open until filled. Apply to:

\section{Carolyn J. Henderson \\ Director of Personnel and \\ Organizational Development \\ Doheny Memorial Library \\ University of Southern California \\ University Park \\ Los Angeles, CA 90089-0182}

Applicants should submit letter of application, resume, and names and phone numbers of at least three references. Please refer to Library Systems Analyst, Position \#120-CRL on correspondence. 
ference, INNOVACQ acquisitions. Minimum requirements: ALAaccredited MLS; 5 years progressively responsible library experience; strong oral/written communication skills; progressive attitude toward information services; commitment to team management; ability to work with faculty, staff, administrators; evidence of professional initiative, planning, motivating, leading. Preferred: Subject masters; current public services, collection development, online catalog, online searching experience; staff, community development experience; successful supervision of professionals; grantsmanship. Salary: $\$ 32,000-\$ 33,000$. Standard fringe benefits. Low cost of living in exciting city. Application review to begin June 15, 1988, and to continue until position filled. Available: June 1, 1988. Send letter of application, resume, names of three references to: Helen $\mathrm{H}$. Spalding, Associate Director of Libraries, University of MissouriKansas City, 5100 Rockhill Road, Kansas City, MO 64110; (816) 276-1531. Must be U.S. citizen or have legal right to work in United States. An equal opportunity institution.

ASSISTANT EDUCATION AND SOCIAL SCIENCE LIBRARIAN (Social Science Specialist), University of Illinois Library at UrbanaChampaign. Position provides reference service, bibliographic instruction, and database searching in the social sciences. Responsible for collection development/management and academic department liaison in assigned staff areas. Works closely with faculty to establish collection priorities. Performs original cataloging and participates in other activities as assigned. Responsible to Education and Social Science Librarian. Required qualifications: a master's degree in library science from ALA-accredited school or its equivalent. Degree or significant academic coursework in at least one of the library's subject areas: anthropology, political science, psychology, sociology, social work, speech and hearing science, and education. Professional library experience in one of these fields may be substi- tuted. Knowledge of the goals and activities of a research-oriented university and the ability to work effectively with its clientele; evidence of research orientation and potential to engage in scholarly research. Preferred: professional experience in an academic or research library. Preference will be given to individuals whose subject backgrounds complement those of current library staff. Desired: Experience in reference services, collection development, cataloging and computer-based bibliographic searching. Reading knowledge of one or more modern Western European languages. Appointment at Assistant Professor level; salary $\$ 20,000$ upwards. Send letter of application describing preparation in the above disciplines, as well as relevant library experience, and complete resume with names, addresses, and telephone numbers of four references to: Allen $\mathrm{G}$ Dries, Library Personnel Manager, Library Personnel Office, $127 \mathrm{Li}$ brary, University of IIIInois Library at Urbana-Champaign, 1408 West Gregory Drive, Urbana, IL 61801; (217) 333-8169. Application/ nomination deadline: June 30,1988 . AA/EEO employer.

ASSOCIATE PRESERVATION LIBRARIAN, University of Michigan. Responsible for the management of the Brittle Book Replacement Office which includes procedures for grant-based projects and for the planning, implementation, and supervision of ongoing improvements in the brittle books program. In addition, the Associate Preservation Librarian is responsible for monitoring workflow, hiring and evaluating full-time staff, preparing unit plans and monthly reports, assessing budget and staffing needs, and managing materials funds for reprints and commercial microforms. Will also be responsible for preservation staff and user education program, for disaster planning and training in disaster recovery techniques and for advising selectors on replacement decisions. Assists the Head, Preservation Office, in writing reports and grant proposals and will manage the funds for preservation supplies and equipment. Required: MLS

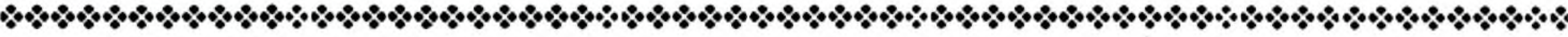

\section{DEAN OF LIBRARY SERVICES}

University of New Orleans

The University of New Orleans invites applications and nominations for the position of Dean of Library Services. UNO, a comprehensive urban university which is part of the Louisiana State University System, has a faculty of over 500 and an enrollment of more than 16,000 students. UNO offers a bachelor's degree in 60 fields of study, the master's in 55, and doctorate in chemistry, education, political science, psychology and financial economics. The Library has a collection of over 1.5 million volumes housed in a spacious, attractive facility. It employs 24 professional librarians with faculty rank and 34 support personnel

The University of New Orleans is seeking a dynamic person with proven leadership ability who will accept the challenge to shape the future of a major university library. Applicants should demonstrate a service orientation, strong interpersonal skills, the ability to stimulate and develop professional and support staff and to mobilize the interest and support of the larger community on behalf of the Library. The Dean reports to the Vice Chancellor for Academic Affairs, serves as a member of the Council of Academic Deans, and represents the Library to the University administration and the community.

Qualifications: Master's degree in library science from an ALA-accredited institution is required, and a doctorate in an academic discipline or library science is desirable. The candidate should provide evidence of substantial and successful administrative experience in an academic/research library, including planning, budgeting, and personnel management. Experience with information technologies and automated library systems is essential, as well as a demonstrated ability to obtain grants and other outside support. This is a twelve-month position; the salary is competitive and negotiable, minimum $\$ 55,000$. Record of academic achievement should qualify individual for rank of Librarian (Professor).

Applicants should submit curriculum vitae and at least three letters of reference by August 1, 1988 Please send all correspondence to:

\section{Lynn M. Accardo, Chair Library Dean Search Committee Office of Academic Affairs University of New Orleans New Orleans, LA 70148}

The committee encourages nominations and applications of women, minorities, and handicapped persons. 
Minimum of 2 years relevant experience in a large academic or research library. Successful supervisory experience including training and budget responsibilities; broad knowledge of preservation based on work experience, equivalent coursework, or related training; ability to plan and implement projects and to work independently; strong oral and written communication skills, demonstrated ability to work effectively with staff at all levels, representatives of other institutions, and the public. Desired: Reading knowledge of at least two Western European languages; familiarity with RLIN or OCLC database. Minimum salary of $\$ 23,000$ dependent on previous relevant experience. Applications received by July 15, 1988, will be given first consideration. Apply to: Lucy Cohen, Manager, Library Personnel Office, 404 Hatcher Graduate Library, The University of Michigan, Ann Arbor, Ml 48109-1205. A nondiscriminatory, Affirmative Action Employer

BUSINESS SUBJECT SPECIALIST. Search reopened. This position supports a rapidly growing undergraduate and MBA program at

\section{Curator Manuscripts \& Archives}

Applications are invited for the position of $\mathrm{Li}$ brarian V/Specialist V (Curator) in the Rare Books and Manuscripts Division/Manuscripts and Archives Section of the Research Libraries.

Working under the general direction of the Assistant Director for Rare Books \& Manuscripts, the selected individual will supervise the day-to-day operation of the Manuscripts and Archives Section, including assisting in the selection, assignment and training of staff; evaluating procedures and organizational patterns; and recommending new procedures and staffing patterns as appropriate.

Qualifications: MLS and/or Master's degree in the humanities, and formal archival training. Substantial experience in the administration of a manuscripts and archives program in a large repository, including demonstrated ability to survey and appraise archival holdings, prepare finding aids and assist readers in using such holdings. Proven administrative and supervisory abilities. Experience in acquiring manuscripts and archival collections. Experience with the AMC format and with library applications of microcomputers preferred.

Minimum salary: $\$ 32,560$ per year. Closing date: July 15, 1988. Preliminary interviews can be conducted at the American Library Association conference in New Orleans in July; or you may send a letter of application and resume to:

\section{Francine Feuerman \\ Human Resources Department \\ The New York Public Library \\ 8 West 40th Street \\ New York, NY 10018}

Candidates selected for consideration will be contacted for an interview. An Equal Opportunity Employer M/F.

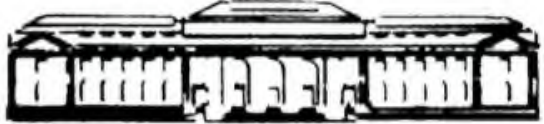

The New York Public Library WHERE YOLR FUTURE IS AN OPEN BOOK a large suburban university. Responsibilities: bibliographic instruction, collection development, database searching and general reference. Qualifications: ALA-accredited Master's degree in Library and/or Information Science; business degree or professional business experience desirable. Professional reference and database searching experience preferred; instructional skills essential. Tenure track position with faculty rank, 12-month contract, excellent fringe benefit package. Salary to $\$ 25,000$ depending upon qualifications and experience. Applications will be accepted until position is filled. Starting date negotiable; August 8, 1988, or earlier preferred. Send resume and names of at least three references to: Angelo Wallace Chairperson of Search Committee, Carlson Library, The University of Toledo, Toledo, $\mathrm{OH}$ 43606. An Equal Opportunity, Affirmative Action Employer.

\section{Librarian IX Assistant Director Cataloging Division}

The New York Public Library seeks an individual with substantial experience in cataloging and classification of library materials.

The selected candidate will be responsible for the overall administration of the Cataloging Division of the Research Libraries, which includes original and copy cataloging of monographs and serials and comprises a staff of more than 50. This individual will also participate in formulating policy in the area of cataloging and bibliographic control

Qualified applicants will have an accredited Master of Library Science and a high degree of expertise in technical processing of research library materials, including those in foreign languages. Must have considerable management experience and demonstrated planning, organization and communication skills. Should have record of continuing involvement in profes sional activities.

Minimum salary $\$ 38,740$, with excellent benefits including 4 weeks vacation. Closing date: July 31, 1988. Preliminary interviews can be conducted at the American Library Association Conference in New Orleans in July, or you may send your resume and covering letter with salary requirements to:

\section{Patricia Dobbins \\ Employment and Placement Administrator \\ The New York Public Library \\ 8 West 40th Street \\ New York, NY 10018}

Candidates selected for consideration will be contacted for an interview. An Equal Opportunity Employer, M/F.

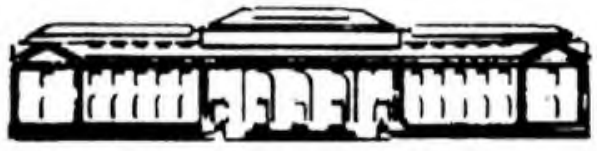

The New York Public Library WHERE YOUR FUTURE IS AN OPEN BOOK 
CATALOGER, LAW SCHOOL LIBRARY. This position is primarily responsible for original and copy cataloging of monographs and serials for the Anglo-American and East Asian collections in the Law School Library. Materials are in English, Chinese and Japanese. The incumbent will also supervise two support-staff copy catalogers working in English, Chinese and Japanese. In addition to an accred ted MLS, requirements are: working knowledge of either Chinese or Japanese; aptitude for analytical and detail work; and working knowledge of automated cataloging systems as demonstrated through previous experience and/or superior performance in forma courses in cataloging and automation. Salary ranges (which will in crease 7/1/88) are currently: Librarian I: \$23,000-\$29,900; Librarian II: $\$ 25,000-\$ 33,750$. Excellent benefits include assistance with University housing and tuition exemption for self and family. Submit resume listing three references to: Kathleen M. Wiltshire, Director of Personnel, Box 35 Butler Library, Columbia University, 535 West 114th Street, New York, NY 10027. Deadline for applications is June 30, 1988. An affirmative action, equal opportunity employer
CATALOGER. Responsible for original and complex copy cataloging of monographs on OCLC according to AACR2; descriptive and subject cataloging using $L C$ classification and subject headings; and appropriate authority work. Will also be involved in implementing a new installation of NOTIS as part of the CUNY + PLUS online integrated library system. ALA-accredited MLS for appointment in the rank of instructor; an additional subject master's degree for appointment in the rank of assistant professor required. Two years recent cataloging experience in an academic library preferred. This is a substitute one year appointment, with possibility of conversion to a regular appointment. Salary from $\$ 24,000$ for instructor; $\$ 25,000$ for assistant professor (may be flexible depending on qualifications); 35 hour work week; four weeks vacation; superior fringe benefits. Send resume, letter of application, and names of three professional references to: Chief Librarian, Baruch College/CUNY, 17 Lexington Avenue, Box 317, New York, NY 10010. AA/EOE

\section{FOUR POSITIONS}

\section{Auburn University}

SCIENCE \& TECHNOLOGY DEPARTMENT HEAD. Along with four librarians and support personnel, provides reference, collection development, bibliographic instruction, and online services. The head has administrative responsibility for the department and assists the Assistant University Librarian for Reference and Information Services and six other department heads in coordinating collections and services. Broad experience in science librarianship required. Proven scholarly record, professional activity at national level, background in science, technical literature, and engineering; second master's or doctorate highly desirable. $\$ 30,000-\$ 38,000$ or higher and appointment as Librarian III (Associate Professor).

SCIENCE \& TECHNOLOGY REFERENCE LIBRARIAN. Provides collection development, reference, and bibliographic instruction services with three other librarians under direction of Science \& Technology Department Head. Reference experience, science background, and evidence of scholarly activity desirable. $\$ 21,000-\$ 28,000$ or higher, appointment as Librarian II (Assistant Professor) or Librarian III (Associate Professor).

\section{Searches Reopened:}

HEAD, VETERINARY MEDICINE LIBRARY. Responsible for campus branch $(27,000$ volumes) reporting to Assistant University Librarian for Reference and Information Services. Responsible for reference and information, training and supervision (2 full-time staff), online searching, collection development, bibliographic instruction and coordination with other departments. Publications, professional activity, and background in biological sciences desirable. Salary $\$ 25,000-\$ 30,000$, or higher, depending upon qualifications and experience.

SERIALS CATALOGER. Reports to Serials Department Head, does original and copy cataloging of serials, series and volumes of monographic series with two other catalogers; supervises one support staff member handling materials with DLC copy; does limited name authority work. Library uses AACR2, LC classification and subject headings, OCLC and NOTIS. Experience and demonstrated analytical or supervisory and training skills, ability to interact effectively with academic community, ability to work unsupervised, excellent communications skills, knowledge of one or more modern European languages preferred. Salary range $\$ 21,000-\$ 25,000$, or higher, depending upon qualifications and experience. Apply to: Thomas R. Sanders, Chair, Serials Cataloger Search Committee, Ralph Brown Draughon Library, Auburn University Library, Auburn University, AL 36849-5606.

\section{General Information Relating to Positions:}

Auburn is a land-grant university, 19,500 enrollment and collection of 1,500,000 volumes. Staff is completing major automation project (NOTIS) and is in final stage of planning for 200,000 square foot building addition. ALA-accredited MLS and strong academic and communication skills required. Appointments for 12 months, faculty status but not professorial titles, eligibility for tenure, participation in state teachers' retirement (mandatory), TIAA/CREF (optional); health, life insurance, and disability benefits; sick leave, 20 days vacation. Applications should include resume, transcripts, and three reference letters specific to positions. Apply to: Robert C. Gibbs, Ralph Brown Draughon Library, Auburn University, AL 36849-5606 (except for Serials Cataloger). 
EDUCATION LIBRARIAN. The Wichita State University Library is seeking a librarian who will act as subject specialist for the College of Education. This librarian will assist users directly at the central reference desk, participate in the bibliographic instruction and collection development programs, provide computer searches, and participate in Reference department decision-making and library and university activities. The successful candidate will be service oriented, able to work effectively with students, faculty, and the general public, and committed to promoting library services and collections to the academic community. An ALA-accredited MLS is required. An additional graduate degree in education or a related field is desired. Wichita State University is an urban institution with an enrollment of 17,000 . The library is fully automated on the NOTIS system. The library building is currently being remodelled and expanded. Librarians at Wichita State enjoy faculty rank, privileges, and responsibilities. Wichita is an active, growing city with a population of 400,000 . Professional activities and conference attendance is supported by the library. Starting salary $\$ 20,000$ to $\$ 28,000$ for 12 -month appointment, depending on experience and qualifications. The successful candidate will be eligible for tenure review. Benefits include TIAA/ CREF, and a choice of Blue Cross/Blue Shield or HMO. Letter of application, resume and names of three references must be received by July 15,1988 . Send to: Sharon L. Bostick, Head of Reference, Campus Box 68, The Wichita State University, Wichita, KS 67208. Wichita State University is an affirmative action, equal opportunity employer.

HEAD, CATALOG DEPARTMENT. Tenure-track, 12-month faculty appointment. Responsible for planning, development of policies and procedures, allocation of resources, and supervision of five faculty and sixteen classified staff. Manages cataloging activities on RLIN and NOTIS, retrospective conversion, bibliographic maintenance and authority control in the card catalogs and the Libraries' automated local system, and processing of materials. Oversees binding, repair of materials and other preservation activities. Coordinates use of RLIN and NOTIS systems within the Department and assists in planning for these systems within the Libraries. Reports to Assistant Director for Technical Services. Requires ALA-accredited MLS degree. At least four years cataloging experience in academic or research library. Knowledge of AACR2, LC Classification, LCSH, and MARC formats. Experience with an automated bibliographic utility and automated local library systems. RLIN and/or NOTIS experience is preferred. Knowledge of preservation, including binding. Planning, organizational, supervisory and training experience. Demonstrated interpersonal skills, including ability to communicate effectively, both orally and in writing. Leadership ability. A record of achievement sufficient to meet the requirements for academic appointment. Potential for meeting the requirements for tenure and promotion. Salary negotiable, minimum $\$ 30,000$. Send letter of application, resume, evidence of degree, and names, addresses and telephone numbers of three references to: Libraries Personnel Office, Colorado State University Libraries, Fort Collins, CO 80523. Review of applications will begin no later than June 27, 1988.

HEAD, CATALOG MANAGEMENT. Oversees 0.5 librarian, 9 support staff and 6-12 hourly staff in: Maintenance of the public online and card catalogs and online union authority files; update of holdings data to reflect materials transfer or withdrawal, or addition of copies or volumes; retrospective conversion; materials preparation; input of bibliographic, authority, and circulation data in support of current cataloging activities. Qualifications: Master's Degree from an accredited library school program; working knowledge of two or more modern foreign languages, preferably including German or a Romance language. Three years professional experience in cataloging and/or catalog management, including significant experience in original cataloging and authority control performed in an automated environment. Demonstrated organizational and supervisory capabilities. Hiring range: $\$ 25,000-\$ 29,000$. Send application and resume including names of references by July 15, 1988, to: Debra Domanico, Library Personnel Manager, Northwestern University Library, Evanston, IL 60208. An Affirmative Action, Equal Opportunity Employer.

HEAD, GOVERNMENT DOCUMENTS AND MAPS DEPARTMENT, Central University Library, University of California, San Diego. Salary Range: Associate Librarian: $\$ 31,008$ to $\$ 44,676$ or Librarian: $\$ 41,700$ to $\$ 57,816$. Under the direction of the Assistant University Librarian-Technical Services, the incumbent is responsible for the leadership, organization, and management of the department. Responsible for organizational and personnel planning includ- ing the selection, training, and evaluation of departmental staff. Provides leadership in developing effective access to and use of information sources in the department and in the provision of new information sources. Assumes a leadership role in developing librarywide services and policies related to use of government publications and maps. Maintains awareness of national and University of California systemwide issues regarding government publications and maps, communicates these issues within the Library, and contributes to the identification and resolution of these issues through appropriate professional activities. Qualifications: Successful experience in program planning, implementation, and management in an academic or research library; knowledge of policies and procedures in academic and research libraries. The ability to manage and provide leadership in a changing environment is essential, as are strong interpersonal skills and the ability to work well with both library staff and users. Demonstrated ability to communicate effectively both orally and in writing is required. MLS from an ALA-accredited library school. Desirable qualifications include: experience in more than one of the following areas: branch library management, public services, technical services, collection development, library instruction, OCLC and/or other automated systems. Experience with or knowledge of issues and trends associated with government publications and maps. UCSD is an equal opportunity, affirmative action employer. Applications received by August 1, 1988, will be assured of consideration. Submit a letter of application, enclosing a resume and a list of references to: Ellen Lawson, Assistant for Academic Personnel, Library, C-075-H1, University of California, San Diego, La Jolla, CA 92093-0047

HEAD, GOVERNMENT PUBLICATIONS DEPARTMENT (search reopened). The University of Nevada-Reno Library, a Land Grant university, seeks a creative, energetic librarian to head an extensive Government Publications Department which is a regional depository for federal documents and a U.S. patent depository. Responsibilities include reference and public service, supervision of 3 library assistants and 1 librarian, collection development, some formal teaching and online searching. ALA-accredited MLS; appropriate experience in a government publications department or in-depth experience with government publications in an academic library. Strong communication, interpersonal and supervisory skills. Computer search experience and experience with microcomputers desirable. Faculty status requires librarians to meet faculty standards for appointment, promotion and tenure. Salary open, depending upon qualifications and experience (minimum: \$29,288). 12-month appointment; TIAA/ CREF; 24 days vacation. Position available immediately. Available for interviews at ALA. Mountains, desert, lakes, 5 hours by car from San Francisco. Send resume and names and addresses of three references to: Mary B. Ansari, Head of Administrative Services, University of Nevada-Reno Library, Reno, NV 89557-0044. Closing date July 20, 1988, or until position filled. AAVOE. UNR employs only individuals lawfully authorized to work in the United States.

HEAD, LC COPY CATALOGING UNIT, Catalog Department, Georgia State University. Responsible for supervision of the work of six LA IIIs in OCLC and circulation terminal work, cataloging monographs with LC AACR2 copy, retrospective conversion, preparation of training materials, planning new procedures, and formulating quality and quantity standards. Online catalog in operation since 1985; online circulation system in use since 1987. Required: ALAaccredited master's in library science, two years cataloging on OCLC or RLIN, one year supervisory experience. Preferred: experience with item records for online circulation. Participation in professional and research activities important. Tenure track, faculty rank and status. Salary: $\$ 21,000-\$ 24,000$. Available July 1988. Submit resume, letter of interest, and names and telephone numbers of current and former supervisors. Materials received by July 15, 1988, will receive priority consideration. Send to: Dianne M. Smith, Library Personnel Officer, Pullen Library, Georgia State University, 100 Decatur Street S.E., Atlanta, GA 30303-3081. An Affirmative Action, equal opportunity employer

hEAD OF GOVERNMENT PUBliCATIONS, Assistant Professor Responsibilities include administration of an extensive Government Publications Department which is a regional depository of federal documents as well as a depository of Mississippi state documents supervision of 3.5 FTE library assistants and a number of student assistants; reference and public service; collection development; and planning for an automated library environment. Position requires ALA-accredited MLS, experience with federal documents, good in terpersonal skills and supervisory experience; additional subject 


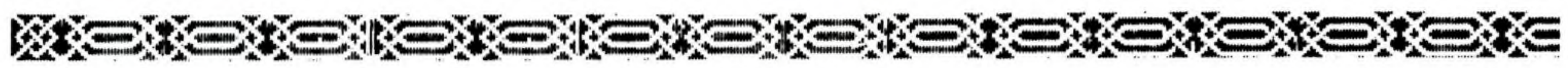 \\ DIRECTOR OF THE BIO-MEDICAL LIBRARY University of Minnesota}

General description: The Director of the Bio-Medical Library is responsible for the administration of the University of Minnesota Bio-Medical Library which interacts closely with and supports the teaching programs of the Schools of Medicine, Dentistry, Nursing, Public Health, the College of Pharmacy, certain biological sciences, and the University Hospital and Clinic. The Bio-Medical Library is located in the health sciences complex on the University's Minneapolis campus and includes a learning resources center, the Wangensteen Historical Library of Biology and Medicine, and an automated technical processing unit. The Library has a total operating budget of more than $\$ 2,000,000$ and a staff of 47 FTE. It has a collection of over 350,000 volumes and 4,000 active journal subscriptions and is one of the stongest collections among health sciences libraries in the country. The Bio-Medical Library has a very active service program and is well positioned for potential IAIMS development.

The Director of the Bio-Medical Library reports to the University Librarian and is a member of the administrative staff of the University Libraries. The Director is an ex-officio member of the Bio-Medical Library Advisory Committee, which meets regularly to advise regarding the programmatic directions of the Bio-Medical Library.

Responsibilities:

-Develops policies and establishes program priorities for the Bio-Medical Library and seeks grant support for innovative programs.

- Has responsibility for the management of the Bio-Medical Library budget and operations.

-Works closely with health sciences departments in the development of programs and services which support the educational, research and information needs of faculty, students, and clinicians.

- Participates in the administration of the University Libraries as a member of the Central Administrative Group and serves on Libraries committees.

-Represents the University Libraries in health sciences matters at local, state, regional and national meetings and participates, as appropriate, in state, regional, and national health sciences library and related professional activities.

Qualifications:

- A graduate degree from a program accredited by the American Library Association is required. An advanced degree in a health related field is desirable.

- A minimum of five years of professional library experience with progressively increasing administrative responsibility, preferably in a large academic health science setting, is required.

-Knowledge and understanding of current issues, trends and problems in academic health sciences librarianship including electronic information systems is required.

-Demonstrated skills and accomplishments in planning and implementing information services is required.

-Demonstrated ability to work effectively with faculty, students, academic administrators, library colleagues, and representatives of the surrounding health sciences community is required.

- Record of substantial professional activities and accomplishments including grant applications and/or publications is required.

- Evidence of the vision and skill to continue the development of an innovative, technologically advanced health sciences library is required.

This is an academic-administrative appointment, which provides a full range of benefits. The salary is competitive and commensurate with experience and qualifications.

Applicants should send a letter of application relative to the above description; a current resume; and names, addresses and telephone numbers of at least five references to:

\section{Barbara Doyle, Personnel Officer, University of Minnesota Libraries, 453 Wilson Library, 309 19th Avenue South, Minneapolis, MN 55455.}

Applications must be received by $\mathbf{9 / 3 0 / 8 8}$. Please cite UL 172 on application.

The University of Minnesota is an equal opportunity educator and employer and specifically invites and encourages applications from women and minorities. Note: The Immigration Reform and Control Act of 1986 requires all new employees to submit verification of identity and authorization to work in the United States at time of hire.

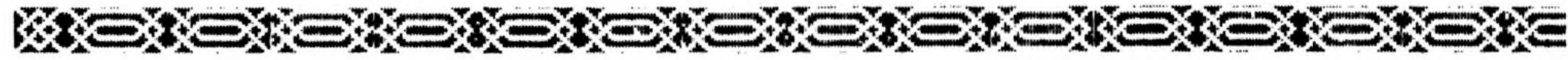


master's or doctorate desirable. Twelve-month appointment; faculty status and expectations. Minimum salary is $\$ 25,000$. Send letter of application, resume, and names, addresses and telephone numbers of three references to: Susan $\mathrm{H}$. Smith, Head of Government Publications Search Committee, Williams Library, University of Mississippi, University, MS 38677. An equal opportunity, affirmative action employer.

HEAD OF SYSTEMS AND OPERATIONS to direct bibliographic control, collection development, serials, and automated services. Requires ALA-accredited MLS plus 3 years experience in some aspect of technical services including management responsibilities. Faculty appointment with 12 month contract, 20 days annual leave, competitive benefits, salary minimum $\$ 26,000$. Apply with letter, resume, and names of 3 references by July 15, 1988, to: Acting Dean, AUM Library, Auburn University at Montgomery, Montgomery, AL 36193-0401. AUM is an Affirmative Action, Equal Opportunity Employer.

HEAD OF THE SCIENCE AND TECHNOLOGY LIBRARY. PoSition description: The Head of the Science and Technology Library will administer a new branch library that will begin operations in 1988 with a satellite information center at the Automation \& Robotics Research Institute reporting to it. The Science and Technology Library will serve all engineering and scientific fields taught on the UTA cam- pus except for medical and psychology programs. The head of the library will supervise and evaluate a staff of two professionals and two classified staff and bear responsibility for reference collection management, reference service, circulation, reserve, binding of current journals, an online search service, the determination of library hours, and management of the Robotics Information Center. The Head of the Science and Technology Library will also collect appropriate statistics, analyze service needs, and make recommendations to the Assistant Director for Public Services that will best serve the library's clientele. The Head of the Science and Technology Library is one of six department heads who report to the Assistant Director for Public Services. Qualifications: Required: Master's degree from an ALA-accredited program; advanced subject degree or the equivalent combination of education and experience in the sciences and/ or engineering; at least four years' library experience in progressively more responsible positions in academic, special, or medical libraries; some supervisory experience; experience in online database searching; a record of professional and/or scholarly activity. Desired: Administrative experience; M.A. or Ph.D. degree in the sciences or engineering. Employment: Full time. Non-traditional work week. Location: The University of Texas at Arlington is located in the Dallas/Fort Worth metroplex, has a current enrollment of approximately 23,000, and offers 97 degrees, 18 at the Ph.D. level. The University Libraries presently have more than $1,000,000$ items in the collections, a staff of 100, and a FY 1987-88 budget of nearly

\section{SYSTEMS LIBRARIAN New Mexico State University}

(Search Reopened.) NMSU enrolls over 14,000 students in 70 major undergraduate areas, 42 master's degree and 19 doctoral degree programs. Celebrating its 100th birthday, NMSU is the land-grant institution for New Mexico. The 5,800-acre campus is located in southern New Mexico on the high desert in the city of Las Cruces. Located 40 miles from El Paso, Texas, at the southern edge of the Rocky Mountains, the area enjoys abundant sunshine, a balmy climate, and yet is within easy driving distance of alpine areas that include excellent skiing and winter sports.

Rank: Faculty or Professional.

Effective date: Screening of applications will begin on July 1, with the search continuing until the position is filled; applications received by June 30, 1988, will be given preference.

Responsibilities: Reports directly to the Associate Dean of Libraries. If tenure track with faculty rank, individual must be prepared to meet library and university criteria for tenure and promotion. Responsibilities include interaction with OCLC, VTLS, Innovacq and the campus computer center. Position will include a wide range of analysis, systems design and specifications, documentation, training, research and coordination between several library, campus and off-campus locations. Evaluation of computer equipment, order specifications, system security and supervision of personnel.

Qualifications: MLS from ALA-accredited program or equivalent other professional degree. Significant experience applicable to library information system design and implementation. Excellent analytical and written and verbal communication skill. Demonstrated ability to work well with individuals and with groups. Work with minimum supervision. Flexibility to meet new assignments as organization and operation changes occur.

Preferred: Three or more years' experience in an academic library; substantial experience with major online computer library systems, especially OCLC, VTLS, and Innovacq; working knowledge of computer hardware, software, programming, and systems analysis; demonstrated ability to write functional specifications, evaluate and implement automated systems; familiarity with MARC formats, library technical services, and commercially available computerized management packages.

Salary: $\$ 32,500$, depending on experience.

Application: Submit letter of application, resume, and names, addresses and telephone numbers of three references to:

\section{Lowell Duhrsen, Associate Dean New Mexico State University Box 30006 \\ Las Cruces, NM 88003}

Initial interview could take place at ALA New Orleans. 
$\$ 5,000,000$. The Libraries participate in AMIGOS/OCLC, DIALOG and BRS, and are installing the NOTIS automated system. Salary and benefits: $\$ 26,000$ annual minimum salary, dependent on qualifications and experience. Benefits include State contribution to health insurance premiums, payment of 88 percent of Social Security premiums for the first $\$ 16,500$ of annual salary for a total of $\$ 965.00$, and 8.5 percent of annual salary contributed by the State to match the employee contribution of 6.65 percent for optional retirement program. Application: Applications should include a resume and the names of three professional references. Consideration for the position will begin July 5,1988 , and will continue until a satisfactory candidate has been found. Applications should be addressed to: Chair, Head of the Science and Technology Library Search Committee, The University of Texas at Arlington, P.O. Box 19497, Arlington, TX 76019. The University of Texas at Arlington is an Equal Opportunity, Affirmative Action Employer.

HEAD, REFERENCE DEPARTMENT, Kent State University Libraries. Reports to the Associate Director for Public Services and Collection Development. Responsible for the administration of a Department, composed of 9.5 FTE professionals and 1 support staff, which includes Bibliographic Instruction, Computerized Information Service (online searching, CD-ROM), and the Reference Desk. Duties include planning and implementing effective, efficient, and innovative methods of sustaining and extending library and information services, the allocation of resources including the selection of information sources appropriate to the mission of the libraries, and the selection, training, and evaluation of staff. Qualifications: Required: ALA-accredited Master's degree. Extensive background and experience in academic reference work, with special emphasis on bibliographic instruction and/or online searching; knowledge of computer technology as it applies to library operations; strong commitment to service; effective interpersonal and communication skills; record of innovation; proven leadership ability/managerial experience and the ability to work with diverse groups and individuals; strong record of research, publication and professional activity; ability to meet the University's requirements for tenure and promotion. Desirable: Second advanced degree. This is a tenure track faculty position. Minimum salary of $\$ 30,000$, with initial academic rank and salary commensurate with education and experience. Deadline for applications is July 31,1988 . Send letter of application, resume, and the names, addresses, and telephone numbers of three references to: Harry Kamens, Budget \& Personnel Officer, Kent State University Library, Kent, OH 44242. Kent State University is an Equal Opportunity Affirmative Action Employer.

HEAD, SERIALS DEPARTMENT, University of Oklahoma. Library faculty vacancy. Duties: Under the general direction of the Director, Library Technical Services, this position is responsible for the management of the Serials Department with approximately 16,000 seria subscriptions; includes supervision and coordination of serials cataloging, periodicals check-in, added volumes/added copies, serials acquisitions, binding, and the Current Periodicals/Microforms Area Supervises one full-time serials cataloger, eight classified staff, and student assistants; responsible for planning, review and implementation of services, procedures and programs for both the processing and public service areas; coordinates all personnel activities including interviewing, hiring, training, evaluating and staff development responsible for production of a computer produced serials holdings list; provides reference service in the Current Periodicals/Microform Area on a regular basis. Qualifications: Required: MLS from ALA accredited library school; four years technical services experience in a library with at least two years professional serials experience, including cataloging; two or more years supervisory responsibility; significant knowledge and experience with an automated system (RLIN, OCLC or the equivalent), AACR2, LC classification and subject headings;-knowledge of at least one European language. Evidence of research and publication. Desirable: Experience in an academic library; demonstrated leadership abilities and supervisory skills; public service experience; strong interpersonal and communication skills; reading knowledge of additional foreign languages second master's degree and/or additional postgraduate work. Deadline for applications: July 5, 1988. Available: September 1 1988. Salary: $\$ 28,000$ minimum. TIAA/CREF; State Retirement System; comprehensive medical protection; 21 days vacation; University holidays; generous sick leave. Employment: Librarians have faculty status, rank of assistant professor or above, privileges, responsibilities, and are eligible for tenure. Application: Send letter of application with resume and the names of three references including current supervisor to: Donald C. Hudson, Manager, Administrative
Services, University Libraries, University of Oklahoma, Norman OK 73019. The University of Oklahoma is an Equal Opportunity, Affirmative Action Employer.

HUMANITIES LIBRARIAN, University of California, Berkeley. Develop and manage extensive range of English language humanities collections excluding art and history and serve as Library liaison with faculty and graduate students. Select current and retrospective materials. perform various kinds of collection evaluation, provide reference service and bibliographic instruction to users of the English languages collections. Participate in and initiate library instructional and orientation programs. Requires MLS degree and graduate work (advanced degree highly desirable) in a Humanities discipline with strong background in English or American Literature; collection development and General reference desk experience in a medium to large academic research library; knowledge of recent advances in literary scholarship and current developments in research libraries. Experience in bibliographic instruction, and experience with automated systems of bibliographic retrieval desirable. Full job description on request. Appointment salary range $\$ 31,008-\$ 47,652$ per annum. Open until filled; candidates applying by 15 July 1988 will be given first consideration. Send resume, including names and addresses of three professional references to: Janice $\mathrm{H}$. Burrows, Library Personnel Office, Room 447 Library, University of California, Berkeley, CA 94720 . EEO Employer.

HUMANITIES REFERENCE LIBRARIAN (Search reopened). Re sponsible for collection development, library instruction, computer assisted research, and reference services in the Humanities; scheduled general reference. Faculty position in the department of library public services reporting to the references services supervisor. Required: ALA-accredited MLS; 2 years library reference experience; second subject Master's degree in the Humanities, preferably in English or the Fine Arts. Minimum salary of $\$ 21,000$. Review of applications will begin June 1, 1988. Applications accepted until the position is filled. Position to begin August 16, 1988. Send letter of application, resume and names and telephone numbers of 3 references to: Office of Academic Affairs, Library Search, Western Kentucky University, Bowling Green, KY 42101. An Equal Opportunity, Affirmative Action Employer.

\section{LATIN AMERICA BIBLIOGRAPHER AND SOCIAL SCIENCES} REFERENCE LIBRARIAN (Search Reopened). This position is responsible for development of a strong research collection of materials about Latin America to meet the information needs of faculty, students, and others in the Columbia community. The incumbent will coordinate collection development within the Libraries and will represent the Libraries at appropriate Research Libraries Group meetings; act as liaison with faculty; and assist in the management, preservation and evaluation of the collection. Reference responsibilities relate primarily to the area of Latin American studies and include consultations by appointment, assistance in the area of information sources in many formats, bibliographic instruction and class lectures, preparation of publications and database searching. Requirements are: Ph.D. in a relevant subject area; excellent language skills in Spanish and a reading knowledge of Portuguese; intimate knowledge of the history, politics, economics and cultures of Latin America; ability to communicate effectively verbally and in writing; significant experience in acquiring Latin American research materials; and flexiblity to work effectively and creatively in a complex environment. Significant experience as a Latin America bibliographer may substitute for the Ph.D. An accredited MLS and additional foreign language skills are preferred. Excellent benefits include tuition exemption for self and family and assistance with University housing. Salary ranges (which will increase $7 / 1 / 88$ ) are currently: Librarian I: $\$ 23,000-\$ 29,900$; Librarian II: $\$ 25,000-\$ 33,750$. Send resume, listing three references, to: Kathleen Wiltshire, Director of Personnel, Box 35 Butler Library, Columbia University, 535 West 114th Street, New York, NY 10027. Deadline for applications is June 30, 1988. An Affirmative Action, Equal Opportunity Employer.

MAP AND GEOGRAPHY LIBRARIAN, Clark University, Worcester, Massachusetts. Reports to University Librarian. Collection en compasses 165,000 maps, 1,600 atlases, and aerial photographs. Full depository for USGS/DMA; selective housing agreement for GPO items with local depository. Responsible for overall administration of Map Library, including collection development, materials acquisitions and processing, reference services, and staff training/supervision. Serves as library liaison to Graduate School of Geography. Provides subject expertise for development of central 
library geography/geology collection. Qualifications: graduate degree from a program accredited by the American Library Association required. Background in geography or cartography desirable. Knowledge of MARC cataloging practices, preferably on OCLC. Knowledge of reference and acquisitions sources for cartographic and geographic materials. Good oral and written communications skills. The position will be available July 1, 1988. Salary $\$ 19,000-\$ 22,000$, depending on qualifications. An EEO/AA employer. To be assured of consideration, please send letter of application, resume, and names of three references to: Susan S. Baughman, University Librarian, Goddard Library, Clark University, 950 Main Street, Worcester, MA 01610.
MELLON INTERN FOR PRESERVATION ADMINISTRATION, University of Michigan. Responsible for expansion of the Library's preservation program in the divisional and branch libraries. Outlines a broad preservation program for a specific collection, with particular attention to the replacement/reformatting of brittle books; develops and oversees implementation of procedures and workflows; develops and presents training modules for divisional library staff; writes narrative and statistical reports and other documents relative to project. Participates with Preservation Office staff in managing ongoing programs (brittle books replacement, conservation and book repair, bindery preparations, and microfilming) and in planning and implementing new preservation initiatives. Participates in staff and

\section{THREE POSITIONS}

\section{Texas A\&M University}

U.S. DOCUMENTS AND PATENTS LIBRARIAN. Provides comprehensive reference assistance, with an emphasis on U.S. documents and patents, from a collection of U.S. and Texas State documents and technical reports. Maintains depository collections of U.S. documents and U.S. patents. Assists in use of GPO/Le-Pac, NTIS and other CD-ROM products. Supervises two support staff. Assists with bibliographic instruction, and computerized reference services and CAR-Search Services within the Documents Division. Complete description available from Acting Head, Personnel Operations.

Qualifications: ALA MLS. Minimum one year professional (post-MLS) experience required, preferably in government documents or U.S. patents reference. Experience in an academic library and experience with online systems of bibliographic data retrieval preferred. Experience with or knowledge of collection development, bibliographic instruction, and cataloging desirable. Knowledge of microcomputer or laserdisk applications also desirable.

Salary: Minimum $\$ 21,000$ for 10.5 months, $\$ 22,000$ with additional Master's.

HEAD, AUTOMATED CATALOGING DEPARTMENT. Provides overall supervision and management for the Automated Cataloging Department under the direction of the Head, Processing Division. Responsible for copy cataloging, NOTIS database and card catalog maintenance, maintaining authority files and solving authority problems, and marking and labeling of materials. Participates in weekly planning meetings. Department consists of 27 classified staff. Complete description available from Acting Head, Personnel Operations.

Qualifications: ALA MLS. Minimum of three years of progressively responsible, professional (post-MLS) cataloging experience, preferably in an online environment. Demonstrated supervisory skills. Knowledge of MARC formats, AACR2, LC Rule Interpretations, and Library of Congress subject headings required. Must have experience with OCLC or similar bibliographic utility. Experience with NOTIS desirable.

Salary: $\$ 23,000$ minimum for 10.5 months; $\$ 24,000$ with additional Master's.

HEAD, ORIGINAL CATALOGING DEPARTMENT. Provide overall supervision and management for the Original Cataloging Department under the direction of the Head, Processing Division. Department is responsible for all original cataloging for all formats in all languages, and provides descriptive cataloging, LC classification, and LC subject headings as needed for OCLC member input records. Participates in weekly planning meetings. Department consists of 4 entry-level professional librarians, 2 experienced catalogers and 4.5 classified staff. Complete description available from Acting Head, Personnel Operations.

Qualifications: ALA MLS. Minimum four years of progressively responsible professional (post-MLS) cataloging experience, preferably in an online environment. Require at least one year in an academic or large research library. Experience with MARC formats, AACR2, LC Rule Interpretations, and Library of Congress subject headings. Must have experience with OCLC or similar bibliographic utility. Experience with NOTIS desirable. Supervisory and management skills appropriate to the position.

Salary: $\$ 24,000$ minimum for 10.5 months; $\$ 25,000$ with additional Master's.

Benefits: Competitive benefits package. No state income tax. Faculty rank. Closing date: Review of applications will begin July 15, 1988. For complete description of duties, qualifications and benefits, and to apply, contact:

\author{
Anna Janne, Acting Head \\ Personnel Operations \\ Evans Library \\ Texas A\&M University \\ College Station, TX 77843-5000 \\ (409) 845-8111
}


user education program, and in disaster preparedness and recover training progrom. In addition, will be responsible for overseeing spe cial projects as assigned; preparation of samples and surveys as needed; participation in planning and implementing grant-based initiatives. Supervision of staff and student employees may be required in carrying out responsibilities. Reports to Associate Preservation Librarian. Required: MLS. Minimum of 5 years' post-MLS experience ability to plan and implement projects and to work independently; strong oral and written communication skills; demonstrated ability to work effectively with staff at all levels, representatives of other institutions, and the public. Desired: Experience in a large academic or research library; successful management experience including planning, supervision, training, and budget responsibilities. Salary commensurate with current level of experience up to a maximum of $\$ 30,000$. Full benefits package. Applications received by July 15 1988, will be given first consideration. Apply to: Lucy Cohen, Manager, Library Personnel Office, 404 Hatcher Graduate Library, The University of Michigan, Ann Arbor, MI 48109-1205. A nondiscriminatory, Affirmative Action Employer

MUSEUM LIBRARIAN. Responsibilities: Administration of a 40,000 volume art library, including provision of reference services and research in support of museum staff; collection development; preparation and implementation of library budget; supervision of staff of 4 including 1 professional, plus volunteers. Required: ALA-MLS; BA in art history; working knowledge of 1 or more European languages; 3 years increasingly responsible professional experience in a museum, research, or academic library. Preferred: MA in art history or related degree. Benefits: Full benefit package, including vacation and sick/personal leave, health and life insurance, retirement plan. Salary: minimum $\$ 25,000$. Send resume with letter and names of 3 references by 15 August 1988 to: Search Committee, The Chrysler Museum, Olney Road \& Mowbray Arch, Norfolk, VA 23510 AA/EOE

OFF-CAMPUS LIBRARIAN (Anticipated opening). Opportunity to join an excellent team of 11 professional librarians in providing service to a large, multi-campus, urban community college. Duties: To supervise and develop LRS off-campus operations (three centers and four sites) and offer general reference service and library use instruction at branch campuses and off-campus centers. ALA accredited MLS. Two years' experience. Supervisory experience preferred. Local travel required (reimbursed). Applicants should be flexible, curious, energetic, and knowledgeable, with excellent communication skills. Minorities are encouraged to apply. Faculty status nine-month contract with three-month summer option. Salary $\$ 21,076$ (nine months) minimum. Respond with letter of application resume, and names and addresses of three references to: Personne Department, Austin Community College, P.O. Box 2285, Austin TX 78768. Closing date: July 11, 1988. Screening at ALA. ACC is an

\section{TWO POSITIONS}

\section{Purdue University}

FOREIGN LITERATURE BIBLIOGRAPHER/REFERENCE LIBRARIAN. Requirements: MLS (ALAAccredited). Minimum of 2 years academic library experience in collection development and maintenance in humanities, including foreign languages and literature. Desired Qualifications: Collection development/ maintenance experience with library materials in all formats; reference experience; advanced degree, Ph.D preferred, in either comparative literature or one of the following modern literatures: Spanish, German, French or Russian; teaching experience on the academic level; experience using online systems. Responsibilities: Development and maintenance of the collection in foreign languages and comparative literatures, and allied humanities disciplines. Participates in reference service part time, providing general and specialized reference. Expected to teach a course in Department of Foreign Languages and Literatures during Fall and Spring Semesters.

SOCIAL SCIENCE BIBLIOGRAPHER/REFERENCE LIBRARIAN. Requirements: MLS (ALAAccredited). Minimum of 2 years academic library experience in reference service, collection development and maintenance in the Social Sciences. Desired Qualifications: Experience with library materials in all formats; advanced degree in a social sciences discipline; and experience in searching online bibliographic databases. Responsibilities: Development and maintenance of the collection in sociology and anthropology, and audiology and speech sciences. Provides general and specialized reference service.

Salary: $\$ 20,000$ and up depending upon qualifications.

Status and Benefits: Faculty status and responsibilities. Members of the Library faculty must meet Purdue University requirements (excellence in librarianship, research and publishing, and service) for promotion and tenure. Rank commensurate with education and experience. Twelve month appointment with 22 days vacation accrual. Flexible benefits programs with open enrollments annually. Group life, medical and disability insurance programs are in effect as are TIAA/CREF and Social Security coverage.

Libraries: The Humanities Library is the principal library resource for the School of Humanities, Social Science and Education, and also serves the general university. The library contains about 700,000 volumes, 750,000 microforms, and 7,000 current serial publications. The library has 42 employees including 13 faculty and professional staff members.

Purdue University Libraries system, which is made up of the Undergraduate Library and 14 school and departmental libraries, has holdings of over $1,600,000$ volumes. Staff totals more than 200 , including 55 faculty and professionals.

Purdue University is located approximately 60 miles northwest of Indianapolis, Indiana. The greater Lafayette area of approximately 100,000 provides a diversity of cultural and social activities.

Application Process: Send resume and list of references to: Thomas L. Haworth, Personnel Officer, Libraries, Stewart Center, Purdue University, West Lafayette, IN 47907. Deadline for Applications: August 1, 1988, or until position is filled. 


\section{PUBLIC SERVICES LIBRARIAN/MICROCOMPUTER SPECIAL-}

IST (search extended). Responsibilities include the computerization of the internal operations of the library. Additional responsibilities include: supervision of the Periodicals Department and shared re sponsibilities in the public service area, including: reference, library use instruction, and collection development. An ALA-accredited MLS and a minimum of three years' professional experience with a working knowledge of dBase III Plus, LOTUS 1-2-3, and word processing. This is a 12-month, tenure track appointment with research and publication required for tenure and promotion. Evening and weekend hours required. Salary range $\$ 24,000-\$ 27,000$. Fringe benefits include 22 vacation days, TIAA/CREF, and Blue Cross/Blue Shield/HMO options; major medical, dental, and life insurance. Starting date July 1, 1988. Applications will be accepted until suitable candidates are found. To apply, send letter of application, including a statement of your philosophy of library service in a small college library, resume, transcript, and three letters of professional reference to: Janet Valeski, Chairperson, DEC, Quinnipiac College Library, Mt. Carmel Avenue, Hamden, CT 06518. An affirmative action employer, equal opportunity. We encourage women and ethnic minorities and other qualified candidates to apply.

RARE BOOK BIBLIOGRAPHER/CATALOGER. Responsibilities: Provides internal bibliographic control, and limited processing of manuscript and related materials. Assists Curator of Rare Books and Manuscripts in selection, evaluation and disposition of rare books and other special materials. Creates bibliographic records (original and adaptive) for printed rare book collections, and assigns, trains, and revises staff performing copy cataloging of other special collections. Provides reference service for rare books. Participates in formulation and implementation of policies and procedures for bibliographic control and management of special collections. Contributes to productivity and quality control goals through own work and effective monitoring of work of assignees. Assists in planning overall library services and programs through committee and task force service. Position administratively is in Special Collections and reports to the head of the department; cataloging is overseen by the head of the Bibliographic Services Department. Temple University Libraries operate an integrated library system (GEAC), including an online catalog. Qualifications: MLS degree from ALA-accredited program and a broad liberal arts educational background. 1-2 years of professional cataloging experience (preferably with rare books and manuscripts) in a large academic or research library or an equivalent combination of education and related experience; knowledge of AACR2, LC Classification and LCSH, USMARC formats, and RLIN or similar bibliographic system; reading knowledge of two foreign languages, preferably German, French or Italian; effective communication, problem solving, and interpersonal skills. Experience with preparation of descriptive bibliographies and familiarity with integrated library systems highly desirable. Salary: Annual salary of $\$ 19,845$ at Librarian II, depending on qualifications and experience, for ten (10) month contract. Liberal fringe benefits include health, dental, and life insurance; tuition remission; TIAA/CREF. Apply to: Pamela Thaxter, Chair, Search Committee, c/o Administrative Services Department, Temple University Libraries 017-00, Temple University, Philadelphia, PA 19122. Send resume and names of 3 references by June 20, 1988. AA/EEO.

REFERENCE/BIBLIOGRAPHIC INSTRUCTION LIBRARIAN, Michel Orradre Library, Santa Clara University. Responsible for coordinating general and course-related library instruction program. Provides reference assistance and searches online databases. May be assigned collection development responsibilities in one or more areas. Required: MLS from ALA-accredited program and 2-3 years relevant professional experience; prior experience in bibliographic instruction, reference, and online searching; strong interpersonal and communication skills. Desirable: academic background in the social sciences; knowledge of at least one modern foreign language. Santa Clara is a Jesuit university located 46 miles south of San Francisco in the heart of California's Santa Clara Valley. Initial appointment at Senior Assistant Librarian rank. 87/88 salary range $\$ 24,916-\$ 35,880$. Apply by August 1,1988 , to: Elizabeth M. Salzer University Librarian, Michel Orradre Library, Santa Clara University, Santa Clara, CA 95053. Santa Clara is an Affirmative Action, Equal Opportunity employer.

REFERENCE SERVICES LIBRARIAN/ASSISTANT DIRECTOR for Wheelock College Library. Position available July, 1988. Respon- sibilities include coordination and provision of reference desk service, bibliographic instruction, and computer searching. Implementation of online catalog services; some collection development. Qualifications: ALA-accredited MLS, strong instructional, interpersonal, and organizational skills, and minimum of 3 years reference experience required. Teaching experience desirable. Salary minimum of $\$ 24,000$. Send resume and names of 3 references by June 30, 1988, to: Andrea Hoffman, Library Director, Wheelock College Library, 132 The Riverway, Boston, MA 02215. Wheelock College is an equal opportunity, affirmative action employer.

SCIENCE REFERENCE/INSTRUCTION LIBRARIAN, University of Wisconsin-Parkside. The successful candidate will provide reference and research assistance; participate in bibliographic instruction program including advanced course-related instruction; participate in collection development, serving as library liaison to severa science departments; participate in a variety of library outreach programs; and coordinate one or more administrative functions within the Public Services Division. Qualifications: ALA-accredited master's degree in library science; science subject background; interest in bibliographic instruction; excellent oral and written communication and interpersonal skills; familiarity with microcomputers and various other information technologies or demonstrated ability to attain these skills. Desirable: two years of relevant experience in an academic library. Salary from $\$ 19,000$ depending on qualifications. Ap plications received before June 30,1988 , will receive priority consideration. Send letter of application, resume, and names and addresses of three references to: Judith Pryor, Chair, Search and Screen Committee, University of Wisconsin-Parkside, Box 2000 Wood Road, Kenosha, WI 53141. UW-Parkside is an Equal Opportunlty, Affirmative Action Employer.

SENIOR SERIALS CATALOGER. Catalogs and classifies classedtogether serials; catalogs series analytics and periodicals in ail subject fields and in a variety of languages and formats. Organizes, supervises, and revises work of Series Analytics paraprofessional Assists Head of Serials Department in the areas of supervision, revision, training, and staff and patron interaction. Contributes to the de velopment of departmental policies and procedures. Required: ALA-accredited MLS, cataloging proficiency in at least one foreign language, experience with LC classification and subject headings and AACR2, familiarity with OCLC system, and three years relevant professional experience. Desired: Supervisory experience. Experience with NOTIS or other integrated library automation system. Sal ary range: $\$ 18,255-\$ 23,860$, based on qualifications. TIAA/CREF group life, medical, dental. Applications will be accepted until the position is filled. Apply to: Wilson Snodgrass, Associate Director, Central University Libraries, Southern Methodist University, Dallas, TX 75275. An affirmative action, equal opportunity employer.

SENIOR SUB-LIBRARIAN, University of Hong Kong. Applications are invited for the post of Senior Sub-Librarian in the Fung Ping Shan Library. The Fung Ping Shan Library has a rapidly growing collection of over 300,000 volumes of East Asian language books and materials, mainly Chinese, but with an increasing proportion of Japanese materials. More than 1,000 periodical titles are subscribed to. In addition to the Senior Sub-Librarian, there are 20 staff, 3 of whom are professionals. Applicants should have a higher degree or postgrad uate diploma in librarianship (MLS, ALA or equivalent), and at least five years' experience in a senior supervisory capacity in an academic library. Applicants will also be expected to have a good academic background in Chinese studies and be able to speak Cantonese and Putonghua. A knowledge of Japanese will be an advantage. Applicants must have extensive working experience with Chinese materials and proven administrative ability. The library systems are already partly computerized and experience with computerized systems for Chinese library materials is highly desirable. The appointee will be responsible for the overall management of the Fung Ping Shan Library and will, under the Librarian's direction, assist in the administration of the Libraries. Annual salary (superannuable) is on a 6-poirit scale: H.K. $\$ 292,320-\$ 355,200$ (U.S. $\$ 1=$ H.K. $\$ 7.80$ equivalent as of March 29, 1988). Starting salary will depend on qualifications and experience. At current rates, salaries tax will not exceed $161 / 2 \%$ of gross income. Housing at a charge of $71 / 2 \%$ of salary, children's education allowances, leave, and medical benefits are provided. Further particulars and application forms may be obtained from: The Association of Commonwealth Universities (Appts), 36 Gordon Square, London WC1H OPF, or from: The Appointments Unit, Registry, University of Hong Kong, Hong Kong. Closes 8 July 1988. 
SERIALS CATALOGER (Search reopened). Responsible for cataloging and classifying print serials in all subject areas. Supervises the serials cataloging unit of two FTE technical assistants and two student assistants. The unit is also responsible for the creation and maintenance of local data records for the Arkansas Union List of Serials via the OCLC Serials Control Subsystem and for recording loca holdings information on the shelflist. Participation in automation planning may also be required. Position reports to the Head, Cataloging Department. ALA-accredited MLS, serials cataloging experience (preferably in an academic library), knowledge of AACR2 and LC classification and subject headings required; experience with OCLC and local automated systems desired. Rank and salary dependent upon qualifications and experience, $\$ 19,000$ minimum. Twelvemonth, tenure-track, TIAA/CREF, 22 days annual leave, tuition and other benefits. Position available July 1, 1988. Applications accepted until the position is filled. The University of Arkansas, Fayetteville, is a land-grant university and the major academic research institution in the state, offering a full range of undergraduate, graduate and professional degrees. Situated in the Ozarks, Fayetteville (population 40,000) offers cultural and recreational opportunities associated with natural beauty and a university community. Send letter of application, resume, and the names, addresses, and telephone numbers of three current references to: John A. Harrison, Director of Libraries, University of Arkansas, Fayetteville, AR 72701. The University of Arkansas is an equal opportunity, affirmative action employer; minority and female candidates are strongly encouraged to apply.

SERIALS CATALOGER. The University of West Florida is seeking a Serials Cataloger responsible for original cataloging and supervision of copy cataloging of all serials. The position reports to the Head of the Serials Unit and works closely with two library technical assistants and several student assistants. Qualifications include knowledge of LC classification and subject headings, OCLC and AACR2. An ALA accredited MLS and two years academic library experience cataloging serials or similar materials are required. Good interpersonal and communication skills are important. Familiarity with government docurnents and microcomputers is desirable. The University of West Florida is part of the state university system and participates in the statewide automation system using NOTIS software. More than 500,000 volumes and 700,000 microform pieces are in the collection. The library subscribes to 4,000 serials and is a partial government documents depository. Available August 1, 1988, at a minimum salary of $\$ 20,000$ plus fringe benefits. Submit letter, resume, and three letters of reference or placement folder to: Grady Morein Library Director, The University of West Florida, 11000 University Parkway, Pensacola, FL 32514. Closing date for accepting applications is July 15,1988 . Indicate availability for interview at ALA. UWF is an Equal Opportunity, Affirmative Action Employer.

SERIALS LIBRARIAN, George Mason University. Manage serials department currently using LINX and preparing to migrate to new integrated library system. Work with liaison librarians on collection development and supervise the library's participation in union list project of Washington Research Library Consortium. Qualifications: ALA-accredited MLS and experience with serials, preferably with automated systems. Supervisory experience and interest in public service desirable. Salary $\$ 24,000$ and up depending on qualifications. Send resume, names, addresses, and telephone numbers of three references to: Florence Landon, Fenwick Library, George Mason University, 4400 University Drive, Fairfax, VA 22030. Applications received by July 8,1988 , will receive first consideration but recruitment will continue until position is filled. Preliminary interviews may be conducted at ALA New Orleans. AA/EOE.

LATE JOB LISTINGS

ASSOCIATE HEAD LIBRARIAN, Simon's Rock of Bard College. To supervise library services at the Simon's Rock College Library and coordinate services with the library program at Bard College. Principal responsibilities include the direction of technical reader services and budget preparation, planning and implementation of automated systems, 'database searching, collection development, and bibliographic instruction. MLS from an ALAaccredited program; minimum five years' experience related to the duties of the position required. OCLC experience preferred. Salary $\$ 25,000$, plus competitive benefits. Application deadline June 30, 1988. Send resume and letter of application with three references to: David C. Tipple, Head Librarian, Bard College, Annandale-on-Hudson, NY 12501. EEO/AA.

AUDIO-VISUAL LIBRARIAN, Kenyon College. Duties: develop, manage, and maintain the resources and services of the Audio-Visual Department of the libraries; develop and manage collection with regard to collegiate needs; originate and conduct instructional programs; supervise support staff; develop department budget in consultation with library director; oversee AV equipment: perform general library duties. Qualifications: ALA-accredited MLS; thorough knowledge of AV resources collection development and computerized collection management; two years experience; knowledge of art history highly desirable. Salary: mid \$20s; negotiable depending on qualifications. Send application, resume, and supporting materials to: Director of Libraries, Kenyon College, Gambier, OH 43022. Deadline: July 1, 1988, or until position is filled; preliminary interviews at ALA conference; starting date August, 1988. Kenyon College is an undergraduate liberal arts college enrolling 1,500 students, located in rural central Ohio. The college, an equal opportunity employer, encourages applications from women and minority members.

CATALOGERS (FOUR POSITIONS), Cornell University Library. The Cataloging Department in Central Technical Services at Cornell is a large department (31 staff) using NOTIS for processing records since April 1988 (RLIN, 1981-1988; OCLC, 1973-1981) and adhering to AACR2, LC 
classification, LCSH, and MARC formats for bibliographic and authority records. The department consists of an Original Cataloging Unit and a Copy Cataloging Unit. Due to the retirement of three long-term catalogers and another opening, four original cataloging positions are now available. Head, Original Cataloging Unit. The unit head serves as cataloging expert and policymaker, trainer of new original catalogers, and supervisor of the unit. Substantial cataloging experience, including authority work, required; supervisory experience and language facility highly preferred. Original Catalogers (3). One year of cataloging experience preferred. Each of these original catalogers, as well as the head of the unit, is required to have a good working knowledge of a language or language group. Preference will be given to experience with AACR2, LCSH, LC classification, MARC formats, NOTIS, RLIN. Specific language expertise not tied to either unit head or other cataloging positions; retiring catalogers' languages include German and related languages, French, Italian, Latin and Greek; and Russian and other Slavic languages. We are also seeking a cataloger with Icelandic and Scandinavian languages. Qualifications required: Fifth year degree from accredited library school; evidence of professional commitment. Salary: $\$ 19,500$ minimum. Depending on qualifications and experience. To apply: Please send cover letter, resume and list of three references to: Ann Dyckman, Personnel Director, Cornell University Library, 201 Olin Library, Ithaca, NY 14853-5301. Applications requested by July 1, 1988. Cornell University is an Equal Opportunity, Affirmative Action Employer.

CATALOGERS (TWO). Catalog and classify book and non-book formats in all Western European languages and all subject fields using AACR2, LC classification and subject headings, and the RLIN cataloging system. Requires: Accredited MLS, Subject Master's degree for tenure. Working knowledge of at least two Western European languages; at least one year experience cataloging and classifying materials on a national bibliographic utility using AACR2 and LC classification and subject headings; familiarity with automated cataloging systems and MARC formats. Faculty status, tuition remission, TIAA/CREF or alternative pension program, five weeks annual vacation. To ensure consideration, send resume and letter of application, including the names, addresses and telephone numbers of three references by June 30, 1988, to: Alice Deich, Personnel Representative, New York University Libraries, 70 Washington Square South, New York, NY 10012. Minimum: \$25,000. New York University is an Equal Opportunity, Affirmative Action Employer.

COLLEGE LIBRARIAN. Juniata College is seeking an experienced academic librarian to provide strong leadership for its library and audio-visual services. Responsibilities include overall management of the library and audio-visual department, supervision of professional and support staff, development of the annual budget, application of information technology, enhancement of student access to materials and promotion of active use. Solid academic credentials, imagination, enthusiasm, understanding of library technology and commitment to undergraduate education in a liberal arts setting are essential. This is an administrative position reporting to the Academic Dean; open appointment date. Salary commensurate with experience; range begins at $\$ 36,000$. Preliminary interviews will take place at ALA New Orleans. Juniata is a selective, independent college of 1,100 students in rural central Pennsylvania. The library is in the middle of a retrospective conversion and reclassification project and is a leader in small library automation. Please send letter of application, resume and the names of three references before July 15, 1988, to: Barbara M. Rowe, Director of Personnel Services, Juniata College, Huntingdon, PA 16652. EOE. 
RARIAN. Responsibilities: Reporting to Head of the Bibliographic Services Department, provides coordination of database management and related activities. Oversees bibliographic and material holdings linking functions and solves bibliographic and automated system problems. Assigns, trains, and revises support staff performing bibliographic control and database maintenance work. Provides bibliographic records (original and adaptive) for materials in a wide range of subjects and formats. Contributes to departmental productivity and quality control goals through own work and effective monitoring of work of assignees. Assists in planning library services and programs through committee and task force activities. Temple University Libraries operate an integrated library system (GEAC), including an online catalog. Depending on qualifications and interests of successful candidate, participation in other areas of library services may be possible. Qualifications: MLS degree from ALA-accredited program program. 1-2 years of professional cataloging experience, preferably in a large academic or research library, or an equivalent combination of education and related experience; knowledge of AACR2, LC Classification and LCSH, USMARC formats, and RLIN or similar bibliographic system; knowledge of two foreign Western European languages, one of them preferably should be German; effective communication, problemsolving, and interpersonal skills. Evidence of professional growth and potential for leadership. Familiarity with integrated library systems highly desirable. Salary: Minimum $\$ 19,845$ at L-2; minimum $\$ 22,050$ at L-3, depending on qualifications and experience, for ten (10) month contract. Liberal fringe benefits include health, dental, and life insurance; tuition remission; TIAA/CREF. Apply to: Penelope Myers, Chair, Search Committee, c/o Administrative Services Department, Samuel Paley Library 017-00, Temple University, Philadelphia, PA 19122. Send resume and names of three references by July 15,1988 . AA/EEO.

DIRECTOR, INSTITUTE OF FINE ARTS LIBRARY. Administers the Institute of Fine Arts Library with a current staff of 8.5 FTE including an administrative employee, 3 clericals and 8 students. Duties include planning, coordinating, developing and directing public service programs such as reference, instruction and orientation, online bibliographic searching and publication of bibliographies and guides, managing collection development, and serving as a liaison with the Technical Services Unit of the NYU Library System. Oversees the Institute's Conservation Center Library. Works closely with the faculty and students of the Institute. Serves as a department head within the Division of Libraries, responsible to the Library's Director of Public and Administrative Services and regularly reports to the Director of the Institute of Fine Arts. The Institute of Fine Arts is among the nation's finest research facilities for the study of the history of art and archaeology and the conservation and technology of works of art. It is located in the Duke House at the corner of Fifth Avenue and 78th Street, close to many of the major museums and art libraries in New York City. Requires: Accredited MLS, graduate degree in art history or related subject area or equivalent experience. Subject Master's degree for tenure. At least five years experience in an art library. Reading knowledge of several Western European languages. Demonstrated skills in personnel and financial management. Familiarity with online systems. Ability to provide leadership and and to work in conjunction with the representatives of other units and the community-at-large. Faculty status, tuition remission, TIAA/CREF or alternative pension program, five weeks annual vacation. Salary commensurate with experience and background. Minimum: $\$ 35,000$. To ensure consideration, send resume and letter of application, including the names, addresses and telephone numbers of three references by June 30, 1988, to: Alice Deich, Personnel Representative, New York University Libraries, 70 Washington Square South, New York, NY 10012. New York University is an Affirmative Action Institution. 
FOUR POSITIONS, Ferris State University. Two Library Faculty positions at Assistant Professor Level, \$25,000 minimum: 1. Cataloger, Library Systems and Operations Department for bibliographic control of monographs, retrospective conversion, and catalog maintenance, coordinating a team of eight or more, using OCLC and implementing library automation of all access and control functions. Required: MLS or equivalent from a library/information science program accredited by the ALA, and a combination of relevant experience or subject area degrees equal to two years, preferably in an academic library's technical services. 2. Health Sciences Librarian in the Department of Reference and Instructional Services to coordinate information resources and services to three professional schools (Optometry, Pharmacy, Allied Health) by establishing a new branch library. Medical Librarian Certification desirable. Required: MLS or equivalent from a library/information science program accredited by the ALA and a combination of relevant experience or subject-area degrees equal to two years, preferably in a medical information center. Two Library Administration positions, Department Heads, \$30,000 Minimum; serve as directors on the Library and Instructional Services Administrative Council: 1. Head, Systems and Operations Department, consisting of Bibliographic Control (Cataloging, OCLC, networking) and Collection Development (Acquisitions and assessment), and liaison with the Computer Center, Academic Computing, and two reference centers, with staff of 3-4 faculty, 2 library assistants, 7 clerks and technicians, plus adult part-time employees and student assistants. Required: MLS or equivalent from a library/information science program accredited by ALA and a combination of relevant administrative and technical experience of 3 years. Demonstrated expertise with bibliographic automated systems, appropriate hardware, and local area network design. 2. Head, Reference and Instructional Services Department, consisting of Reference (manual and online services, and automated reference center), Interlibrary Loan, Library and Bibliographic Instruction, and 2-4 branch libraries and off-site reference centers, with 6-7 faculty, 2 library assistants and a clerk, plus adult part-time employees, student assistants, and interns. Required: MLS or equivalent from a library/information science program accredited by ALA and a combination of relevant administrative and technical experience of three years. Candidates must demonstrate expertise in the program design and delivery of reference services and packaged information, as well as in library/bibliographic instruction and program design, using manual resources, automated information technology, and a variety of media. FSU is a polytechnic university of 11,500 with programs ranging from Associate to Doctorate degrees and schools of Arts and Sciences, Business, Technology, Allied Health, and Pharmacy, a College of Optometry, and a Center for Lifelong Learning. It is situated in Big Rapids, a community of 15,000 fifty miles north of Grand Rapids, Michigan's second largest metropolitan area. The Library and Instructional Services (Academic Computing, Media Production and Distribution, etc.) has a staff of approximately 75 , budgets of over two million dollars, and collections of approximately 1.5 million bibliographic units. Full job descriptions are available; call (616) 592-3611. Apply by June 15, 1988, for possible interviews at ALA with Dean Lawrence McCrank; or by the deadline of July 15, with letters, resume, and 5 references to the appropriate search committee, FSU Library, Ferris State University, Big Rapids, MI 49307. Ferris State University is an Affirmative Action, Equal Opportunity Employer.

GOVERNMENT DOCUMENTS/DATA SERVICES REFERENCE LIBRARIAN. University of Georgia Libraries. The Government Documents Department provides extensive reference assistance in U.S. Government documents, United Nations, Georgia and Canadian documents, British, French, and West German parliamentary documents, and other selected foreign government publications. Data Services, a unit of the Libraries Social Sciences 
Department, maintains a large and increasingly significant collection of machine readable data files obtained through participation in the Georgia State Data Center (U.S. Census) and the Inter-university Consortium for Political and Social Research (ICPSR) as well as from commerical suppliers. (Salary minimum $\$ 18,700$ ). The successful candidate may have the opportunity to participate in an intensive professional development program. Duites: The Government Documents/Data Services Reference Librarian is a new position created to enhance user access to a large government documents collection and a growing resource of machine readable data files. The incumbent will strengthen links between computer-accessed files and printed government information by guiding users to the most appropriate source, regardless of format. This includes providing in-person and telephone reference service which will require in-depth knowledge of the contents of ICPSR and census data collections and published census information; developing familiarity with the collections and maintaining knowledge of reference, bibliographic, and other information sources used to service these collections; participating in the development and evaluation of the policies and services of the departments; and planning and participating in library orientation and bibliographic instruction programs especially in the areas of census and statistical information. The Government Documents/Data Services Reference Librarian reports to the Head of the Government Documents Department and will spend approximately 60\% of the work week in the Government Documents Department and 40\% in the Data Services Unit. Qualifications: ALA-accredited MLS; reference coursework in government documents or relevant experience; strong commitment to public service; interest in the social sciences and quantitative analysis; experience with SPSS, SAS or similar statistical package preferred; interest in bibliographic instruction; ability to establish and maintain effective working relationships; effective oral and written communication skills; interest in academic librarianship preferred. Application procedure: Send letter of application by July 22, 1988, including resume and names of three references to: George H. Libbey, Assistant Director for Administrative Services, University of Georgia Libraries, Athens, GA 30602. This position will be filled only if suitable applicants are found. An Equal Opportunity, Affirmative Action Institution.

GOVERNMENT DOCUMENTS/REFERENCE LIBRARIAN. Responsible for the collection development, staff training and promotion of government documents in an integrated setting within the division of Information Services. Since government documents assistance is provided at the central reference desk, this position involves reference assistance in a variety of subject areas. Contributes to all planning and policy-making decisions related to government documents. Participates in library user education and database searching. The Library is committed to innovative, top quality programs and services demonstrated by an active Library User Education program; pro-active librarian liaison and outreach; acquisition of laser-based reference tools; and an online public access catalog. Documents are cataloged and reflected in the online catalog. Required: ALA-accredited MLS; at least one year of experience with government documents in a medium to large library setting; excellent interpersonal skills; and a strong user-oriented philosophy. Preferred: Background and/or experience in general reference in an academic setting and knowledge of technical processing aspects of government documents. Nine or 12-month negotiable, faculty status/tenure track position. Research and publication are required for tenure. Excellent fringe benefits, state retirement plan, minimum salary range $\$ 18,000-\$ 21,000$. Send letter of application, resume, and names, addresses and telephone numbers of three references to: Kathryn Thiede, Personnel Officer, Dean's Office, Jerome Library, Bowling Green State University, Bowling Green, OH 43403-0170. Review of applications will begin on June 20,1988, and will continue until the position is 
filled. BGSU is a comprehensive university, enrolling approximately 14,000 undergraduates and 3,000 graduate students. BGSU is an AA/EOC employer. Minorities and women are encouraged to apply.

GOVERNMENT DOCUMENTS REFERENCE LIBRARIAN, University of Oklahoma. Library Faculty Vacancy. Duties: Under the general direction of the Head of the Reference Department, this position is responsible for the management of the government publications collections including federal, state, and international documents. This position supervises two full-time clerical staff and student assistants, and is responsible for the planning, implementation, and review of services, procedures, and programs. The incumbent provides reference and bibliographic service in the areas of government publications; provides general reference service at the Library's main reference desk; participates in collection development activities for the government documents collections; performs online bibliographic searches; and provides library instruction in the use of government publications. Qualifications: Required: MLS from ALA-accredited library school; knowledge of database searching and library instruction concepts and methods. Evidence of research and publication. Desirable: academic background in political science, history, or related field; pre-professional or professional experience in a library government documents department and/or library reference department. Effective communication skills. Some supervisory experience. Deadline for applications: August 15, 1988. Available: October 1, 1988. Salary: $\$ 28,000$ minimum. Benefits: TIAA/CREF; State Retirement System; comprehensive medical protection; 21 days vacation; University holidays; generous sick leave. Employment: Librarians have faculty status, privileges, responsibilities, rank of assistant professor or above, and are eligible for tenure. Application: Send letter of application with resume and the names of three references including current supervisor to: Donald C. Hudson, Manager, Administrative Services, University Libraries, University of Oklahoma, Norman, OK 73019. The University of Oklahoma is an Equal Opportunity, Affirmative Action Employer.

HEAD OF INFORMATION SERVICES (Search Re-opened). Provides creative leadership in planning, developing, and administering programs in reference services, collection development, government publications, library instruction, and automated database search services with 13 librarians, 13 support staff, and student employees. Requires ALA-accredited Master's degree; minimum of 4 years experience in information services in an academic library; demonstrated planning, management, and interpersonal skills; excellent written and oral communication skills; and a strong user-oriented philosophy. Candidates must possess a knowledge of emerging information technologies and applications to libraries. Salary $\$ 30,000$ minimum depending on qualifications. Applications received by July 15, 1988, will receive first consideration. Send letter of application, names of 3 references and resume to: Dana Rooks, Assistant Director for Administration, University of Houston Libraries, 4800 Calhoun, Houston, TX 77004. Equal Opportunity Employer.

HEAD OF TECHNICAL SERVICES (tenure-track). Duties and Responsibilities: Manages the technical services operation (acquisitions, cataloging, serials, and binding) consisting of $8 \mathrm{FTE}$; performs original cataloging and serves as cataloging resource professional; plans for, evaluates, and implements automated systems to support operations library-wide. As member of professional staff, provides service at general reference desk, teaches bibliographical resources courses, conducts database searches, and selects materials in one or more subjects for the general collection. Qualifications: ALA-accredited MLS degree, 5 years experience in technical services, supervisory experience required. Experience with OCLC, AACR2, MARC formats, and automated library systems required. Academic library experience 
preferred. Proficiency in one or more foreign languages desirable. Twelve month faculty appointment. Salary and rank (Assistant or Associate Professor) commensurate with experience and qualifications. Send letter of application, resume and names and phone numbers of three references to: Barbara J. Brown, University Librarian, Washington \& Lee University, Lexington, VA 24450. Equal Opportunity Employer. Applications received before June 20, 1988, will receive first consideration.

HEAD, SCHOOL OF LIBRARY AND INFORMATION SCIENCE LIBRARY, Indiana University, Bloomington, Indiana. Assistant Librarian, Associate Librarian, or Librarian. Responsible for working closely with faculty and students to understand information needs and provide appropriate collections and services. Under general direction of Associate Dean for Public Services, responsible for planning, managing, supervising, and evaluating unit's services and operations; has primary responsibility for selection, training, and evaluation of personnel; planning and implementation of user services including computerized services; coordination of the personnel budgets. Under general direction of Associate Dean for Collection Management and Development, responsible for collection management including management of materials budgets to support library science and children's literature, collection evaluation, and preservation. The Head, SLIS, is a member of the Council of Branch Librarians, the Library's Administrative Council, and the Fund Managers Council and participates in library-wide discussion and planning. Qualifications: Master's degree from ALA-accredited library school; supervisory experience; demonstrated ability to plan and evaluate library programs, work with others to attain objectives, manage wide variety of complex library operations; experience with reference sources, collection development, computer-based library services, and instructional techniques; demonstrated ability to communicate logically, clearly, effectively orally and in writing; ability to work well independently and with others; imaginative, innovative, and responsive to change. Successful post-MLS professional library public service experience preferred. Ability to meet responsibilities and requirements of tenure-track appointment. Salary dependent upon qualifications and experience. Minimum: Assistant Librarian, \$21,500; Associate Librarian, $\$ 27,000$; Librarian, $\$ 33,000$. Benefits include: tenure-track appointment; vacation of 22 working days; liberal sick leave; Blue Cross/Blue Shield; group life insurance; TIAA/CREF retirement/annuity plan. Librarians are eligible for sabbatical leaves and other research support. To apply a letter of application stating qualifications and background relevant to this specific position accompanied by resume and names and addresses of four references should be sent to Search and Screen Committee in care of: Marilyn Shaver, Personnel Officer, Indiana University Libraries, Main Library C-2, Bloomington, IN 47405. Telephone: (812) 335-3403. Available: July 1, 1988. Closing date for applications: No earlier than June 20, 1988. EEO/AAE.

HEAD, SERIALS DEPARTMENT, University of Cincinnati. Responsible for the management of the centralized serials acquisitions and cataloging services for the university library. Receives general direction from the Associate University Librarian for Access Services. Supervises a staff of two librarians and 9.5 FTE support staff. University Libraries consist of a main library and 11 college and departmental libraries. The collection includes 1,250,000 volumes, 14,000 subscriptions and $1,625,000$ microforms. This position offers the opportunity to bring together serials acquisitions and serials cataloging functions, to implement an online serials system, and to design and implement new work flow. Required qualifications: MLS from an ALA-accredited program. Demonstrated leadership, management and human relations skills. Five years' experience which includes library serials acquisitions. Successful supervisory experience. Ability to communicate clearly, both orally and in 
writing. Prefer experience with online catalogs and online serials control systems. Public service experience. Serials catalog experience. Salary and rank is commensurate with qualifications and experience. Range: \$28,000$\$ 34,000$. Deadline July 5,1988 . Send resume with cover letter and names of three references to: Judy Wernicke, Personnel Assistant, 640 Langsam Library, University of Cincinnati, Cincinnati, $\mathrm{OH}$ 45221-0033. The University of Cincinnati is an $\mathrm{AA} / \mathrm{EOE}$.

HEAD, SOCIAL SCIENCES AND HUMANITIES DEPARTMENT, Colorado State University. Tenure track, 12-month appointment. Reports to Assistant Director for Public Services. Provides library services in Social Sciences, Business, Humanities, Arts. Bibliographic instruction, reference, database searching. ALA-accredited MLS. Minimum $\$ 30,000$. Contact: Ruth Ludwig, Colorado State University Libraries, 106 Morgan Library, Fort Collins, CO 80523; (303) 491-1834, by July 5, 1988.

HISTORICAL SOCIETY LIBRARIAN (Search reopened). Historical Library seeks a librarian to oversee a comprehensive collection, spanning c.1650 to the present, with special strengths in the history of the Middle Atlantic region and genealogical sources for the Eastern United States. Responsible for collection development and preservation, budget and planning, reference services, and supervising staff of eight. Qualifications: the successful candidate will possess a strong background in American history and historiography, methods and source materials for genealogical and historical research, and automated systems, particularly OCLC and RLIN, and have strong leadership skills. Candidate must possess 3-5 years of supervisory experience; a Ph.D or degree in ALA-MLS and advanced subject degree. Publications and professional visibility highly desirable. Salary range: $\$ 26,000-\$ 32,000$. Send letter, resume, and names of three references to: Librarian Search, Historical Society of Pennsylvania, 1300 Locust Street, Philadelphia, PA 19107. EOE.

HUMANITIES BIBLIOGRAPHER. Coordinates the development of the Bobst Library humanities collection which includes art, English and American literature, music, performing arts, philosophy and religion, Western European languages and literatures, world history and area studies programs for Latin America and the Near East. Oversees and evaluates the work of eight selectors. Serves on the Collection Development Committee and guides the formulation of collection development policy, retrospective selection and collection evaluation for the humanities. Acts as liaison with the teaching faculty. Requires: Accredited MLS, subject Master's degree for tenure. Advanced degree in literature or history preferred. Five years experience as a selector in a university library. An understanding of academic research needs and the nature of scholarly publishing in the humanities in general are required. Demonstrated ability to provide leadership, exercise independent judgment and communicate effectively with faculty. Reading knowledge of French and Spanish essential; working knowledge of German desirable. Faculty status, tuition remission, TIAA/CREF or alternative pension program, five weeks annual vacation. To ensure consideration, send resume and letter of application, including the names, addresses and telephone numbers of three references by June 30,1988, to: Alice Deich, Personnel Representative, New York University Libraries, 70 Washington Square South, New York, NY 10012. Minimum: $\$ 30,000$. New York University is an Equal Opportunity, Affirmative Action Employer.

INSTRUCTIONAL SERVICES LIBRARIAN (Temporary 10-month appointment). Responsibilities: General reference, bibliographic instruction, liaison with faculty. Requirements: MLS from ALA-accredited library school; salary $\$ 18,000$. Position starts September 1, 1988. Review of applications 
begins July 15, 1988, and continues until position is filled. Send letter of application, resume, and names of three references to: Larry Hardesty, Library Director, Eckerd College, Box 12560, St. Petersburg, FL 33733-2560. An Equal Opportunity Employer.

LIBRARIAN. Historic Mount Vernon offers an excellent opportunity for an energetic, dynamic individual to assume a leadership role in the management of Mount Vernon's library. The primary responsibility is the management, acquisition, organization, and conservation of the library's collections. These collections include 10,000 reference and rare books, 5,000 historical manuscript items, graphic art, Association archives, etc. ALA-accredited MLS required. Minimum $\$ 32,480$. Effective communication skills (written and oral), ability to work with all segments of the community and a special sensitivity to the rich historical traditions of the Mount Vernon estate. Send resume with three references to: Director of Personnel, Mount Vernon Ladies' Association, Mount Vernon, VA 22121.

LIBRARY SYSTEMS ANALYST, California University of Pennsylvania. Description of duties: The position entails responsibility for the continuing technical management, design, and development of the library's automated systems including: coordination of communication between library and computer center personnel; continue with the implementation and functional operation of the online catalog; study the feasibility of the integration of the circulation system with the online catalog; production of documentation of systems; coordination and management of activities related to the installation, implementation, and maintenance of both hardware and software in the library in conjunction with computer center personnel; supervision of testing of system enhancements; handling communications with computer hardware and software vendors; evaluation and recommendation of purchases of library computer hardware and software with participation in contract negotiations with vendors; and provision of training in the utilization of library systems. Candidates desiring further information may contact Richard M. Matovich at (412) 938-4096. Desirable qualifications: Master's Degree in Library, Information, of Computer Sciences. Experience with automated library systems or systems analysis and design desirable. Condition of employment: Successful applicant should be able to start employment about September, 1988. Salary range of $\$ 27,409-\$ 41,114$ determined by qualifications and experience. $371 / 2$ hour work week with generous fringe benefits. This is a twelve month managerial position. Final date to apply: August 1, 1988. Submit vita which must include $(a)$ leter of application, $(b)$ current resume, $(c)$ transcripts, and $(d)$ names, summer addresses, and telephone numbers of three references preferably from current or former employers to: Richard M. Matovich, Search Committee Chairperson, Manderino Library, California University of Pennsylvania, California, PA 15419. Description of university and library: California University of Pennsylvania, one of the fourteen state-owned universities of the Pennsylvania State System of Higher Education, is located 40 miles south of Pittsburgh and has an enrollment of 6,000 students. The circulation system and online catalog are supported by DEC VAX computers maintained in the University Computer Center. An Equal Opportunity, Affirmative Action Employer.

ORIGINAL CATALOGER, ICELANDIC \& OTHER LANGUAGES. Cataloging Department, Central Technical Services. Cornell University is seeking an original cataloger of monographic material for the world-renowned Fiske Icelandic Collection. One-half of the assignment will be original and copy cataloging for the Fiske Collection; the second half will be original cataloging in another area, based on language and/or subject skills of the cataloger and department needs (currently material in Germanic and Scandinavian languages 
and in science). Qualifications: Required: Fifth year degree from an accredited library school; reading knowledge of Icelandic and one modern Scandinavian language. Preferred: One year of cataloging experience using AACR2, LC classification and LCSH; experience with the MARC communications format and automated systems (RLIN, NOTIS preferred); other language ability, especially German, Dutch, another Scandinavian language; evidence of professional commitment. Salary: $\$ 19,500$ minimum. Apply to: Please send cover letter, resume and list of three references to: Ann Dyckman, Personnel Director, Cornell University Library, 201 Olin Library, Ithaca, NY 148535301. Applications requested by July 1, 1988. Cornell University is an Equal Opportunity, Affirmative Action Employer.

PHYSICAL SCIENCES LIBRARIAN/COORDINATOR OF CIRES. Coordinates Computerized Information Retrieval Services (CIRES) program including management, training, and evaluation. Supervises 1 FTE. Provides service at information desk. Responsible for collection development, user education, and computerized database searching in Physical Sciences. Requires ALA-accredited Master's degree, significant coursework in physical sciences or science reference experience, and significant experience in database searching. Excellent communication skills and service orientation essential. $\$ 23,000$ minimum salary depending on qualifications. Excellent benefits package. Applications accepted until July 15, 1988, or until position filled. Send letter of application, names of 3 references and resume to: Dana Rooks, Assistant Director for Administration, University of Houston Libraries, 4800 Calhoun, Houston, TX 77004. Equal Opportunity Employer.

PUBLIC RELATIONS OFFICER. 12-month academic faculty or administrative professional appoiptment. Reporting to Director of Libraries, serves as libraries' liaison to Offic of University Communications, University Development Office, Ofñce of spo s ed Research, local businesses. Revitalize Libraries Associates, monitor potent alg ont t. Fxperience in university library preferred. Demonstrated experience in thant wring fund raising, and/or public relations. Minimum $\$ 30,000$. Contact: Ret of d ig, Colorado State University Libraries, 106 Morgan Library, Fort Collins, CO 80523; (303) 4911834 , by July 5,1988 .

PUBLIC SERVICES LIBRARIAN. Juniata College is seeking two creative people-oriented librarians to join our public services team. Responsibilities will include research assistance, online searching, liaison with faculty and supervision of support staff. Incumbents are expected to work with the academic community and share in the development and implementation of a new public services program to promote active library use. Academic year contract, faculty rank, reporting to College Librarian; range begins at $\$ 19,000$. Preliminary interviews will take place at ALA in New Orleans. Juniata is a selective independent college of 1,100 students in rural central Pennsylvania. Send letter of application, resume and the names of three references by July 15, 1988, to: Barbara M. Rowe, Director of Personnel Services, Juniata College, Huntingdon, PA 16652. EOE.

REFERENCE/INSTRUCTION LIBRARIAN. Daytona Beach Community College seeks innovative, service-oriented librarian to fill new entry level position. Duties: Supervision of Sunday afternoon and evening staff, reference assistance, online searching (DIALOG), classroom instruction; prepare bibliographies, etc.; collection development input. Requirements: ALA/MLS, energetic good interpersonal and communication skills, flexibility, knowledge of basic reference sources. 12 month appointment with excellent benefits. Minimum \$22,670. Send letter of application, resume, and 3 references to: Human Resources Department, Daytona Beach Community College, 1200 
Volusia Avenue, Daytona Beach, FL 32015. EOE M/F.

REFERENCE LIBRARIAN FOR FINE ARTS. Reporting to the Head of General Reference, the librarian will manage a Fine Arts reference unit within the main library. Collection includes reference materials in Art, Architecture, Music and Dance. Duties include supervision of full and part-time employees, reference work in Fine Arts with students, faculty and members of the community, collection development as assigned, library instruction, database searching. Required: MLS from an ALA-accredited library school. Preferred: Advanced degree in a Fine Arts discipline, Fine Arts Library experience, reference, instruction and online searching experience, ability to work well with university faculty and students, knowledge of a Western European language. Salary: Minimum $\$ 18,000$. Send letter of application, resume and names of three references and/or placement file address by July 1, 1988 to: Dennis R. Defa, 328 Marriott Library, University of Utah, Salt Lake City, UT 84112. The University of Utah is an Equal Opportunity, Affirmative Action Employer. Women and Minorities are encouraged to apply.

SOCIAL SCIENCE REFERENCE LIBRARIAN. Entry-level position. Permanent, nine-month, full-time appointment; tenure track position with faculty status. Responsibilities: General reference, bibliographic instruction; collection development, online searching and liaison to departments in the social sciences; coordinates special and outreach projects; teaches in school library media program. Required: ALA MLS; training or experience in general reference and online searching. Preferred: second master's in a social science. Second master's required for tenure. Assistant Professor $\$ 21,250-\$ 23,250$ for nine months. Applications received by July 31, 1988, will receive first consideration, but applications accepted until position is filled. Send resume and names, addresses, and phone numbers of three references to: Deborah Hollens, Library Personnel Committee, Southern Oregon State College, Ashland, OR 97520. Equal Opportunity, Affirmative Action Employer.

SYSTEMS LIBRARIAN/SYSTEMS MANAGER, Bucknell University. Responsibilities: implementation and operation of DRA system; supervision of systems operators, daily operation, maintenance and troubleshooting; resource person/trainer for other library automation; liaison with system vendor. Competitive salary, based on experience, minimum $\$ 28,000$. Requirements: Bachelor's degree, liberal arts desired. Strongly preferred: MLS (ALAaccredited); required: significant technical experience with computer-based integrated systems: DRA, GEAC, or CLSI preferred; proven problemsolving/organizational skills; must work well independently and with others. Send resume and names of three current references before June 30, 1988, for maximum consideration, to: Ann de Klerk, Director of Library Services, Bucknell University, Lewisburg, PA 17837. Applications from members of minority groups are strongly encouraged. Expected appointment date September 1, 1988. 

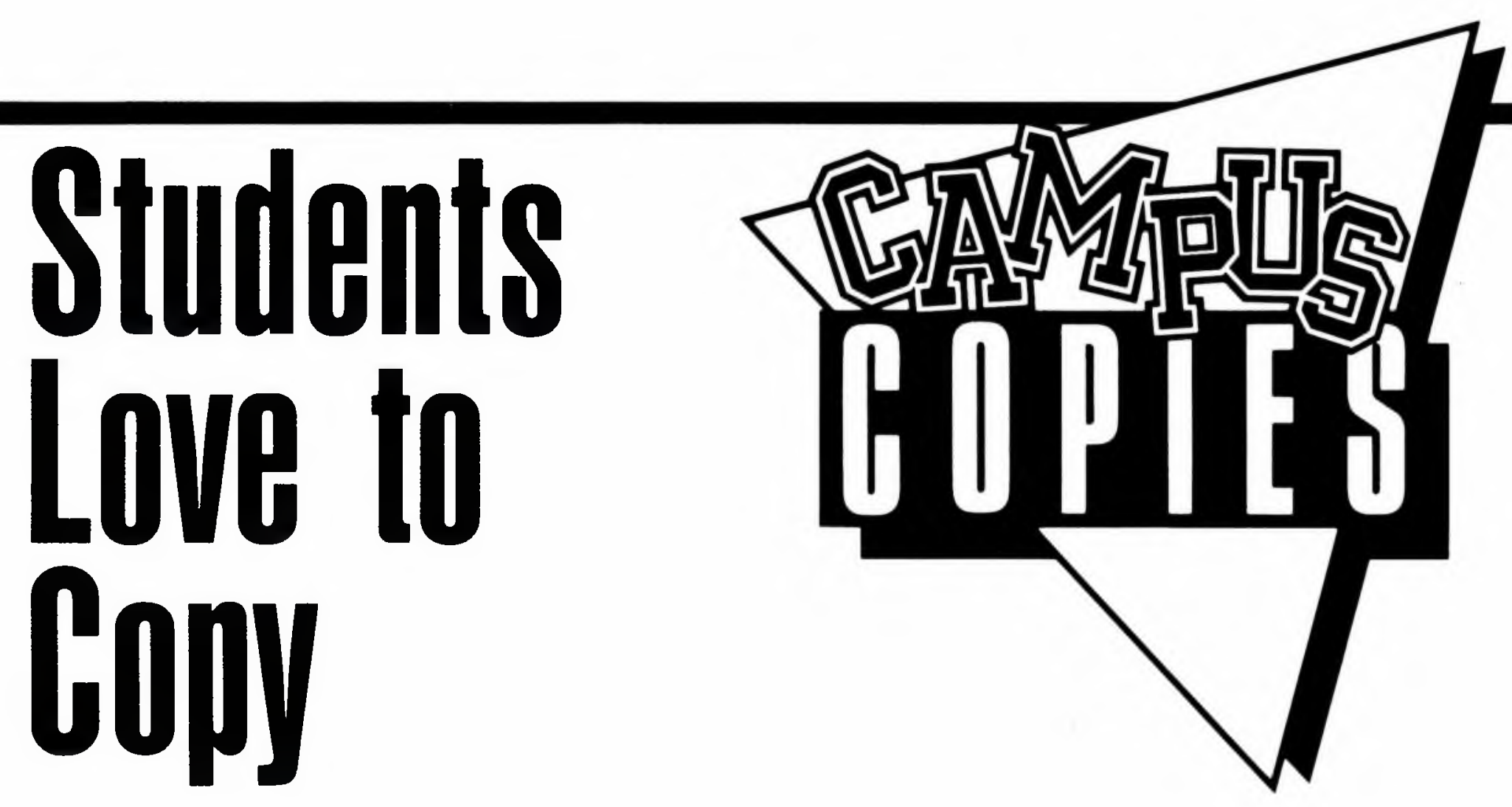

Course materials. . .class notes. . .schedules and party invitations. Students love to copy. And we make it easier for them and for you by providing copy vending management to the university community. In just over six years, we have earned a solid reputation among administrators and students for excellent service, quality copies and reasonable prices. So call or write today and let us show you how to increase uptime, lower book damage and theft, reduce staff involvement and ease maintenance worries.

Campus Copies Corporation

Telephone: 303-449-9247 An Affiliate of Kinko's Copies 4810 Riverbend Road Boulder, Colorado 80301

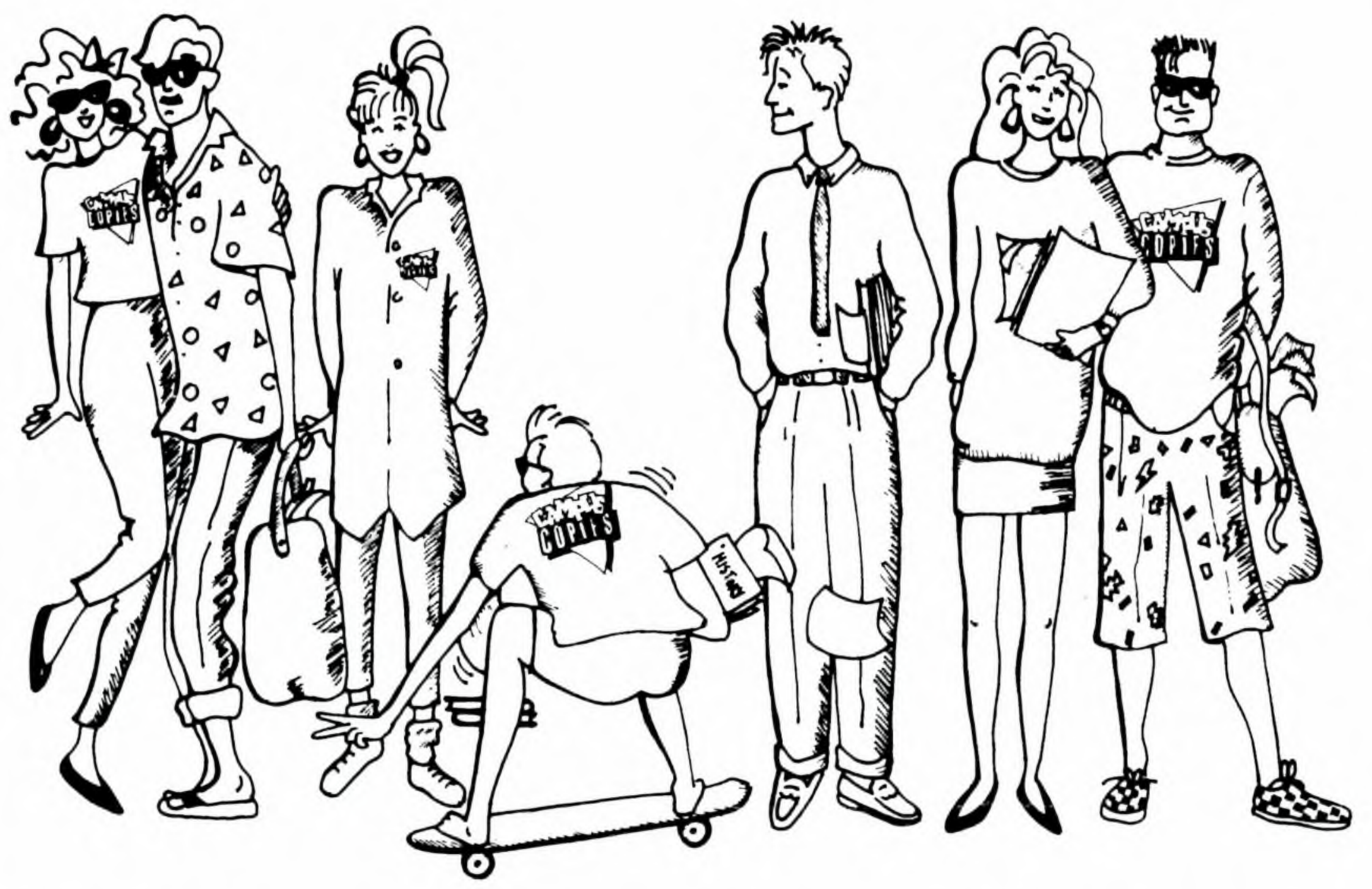




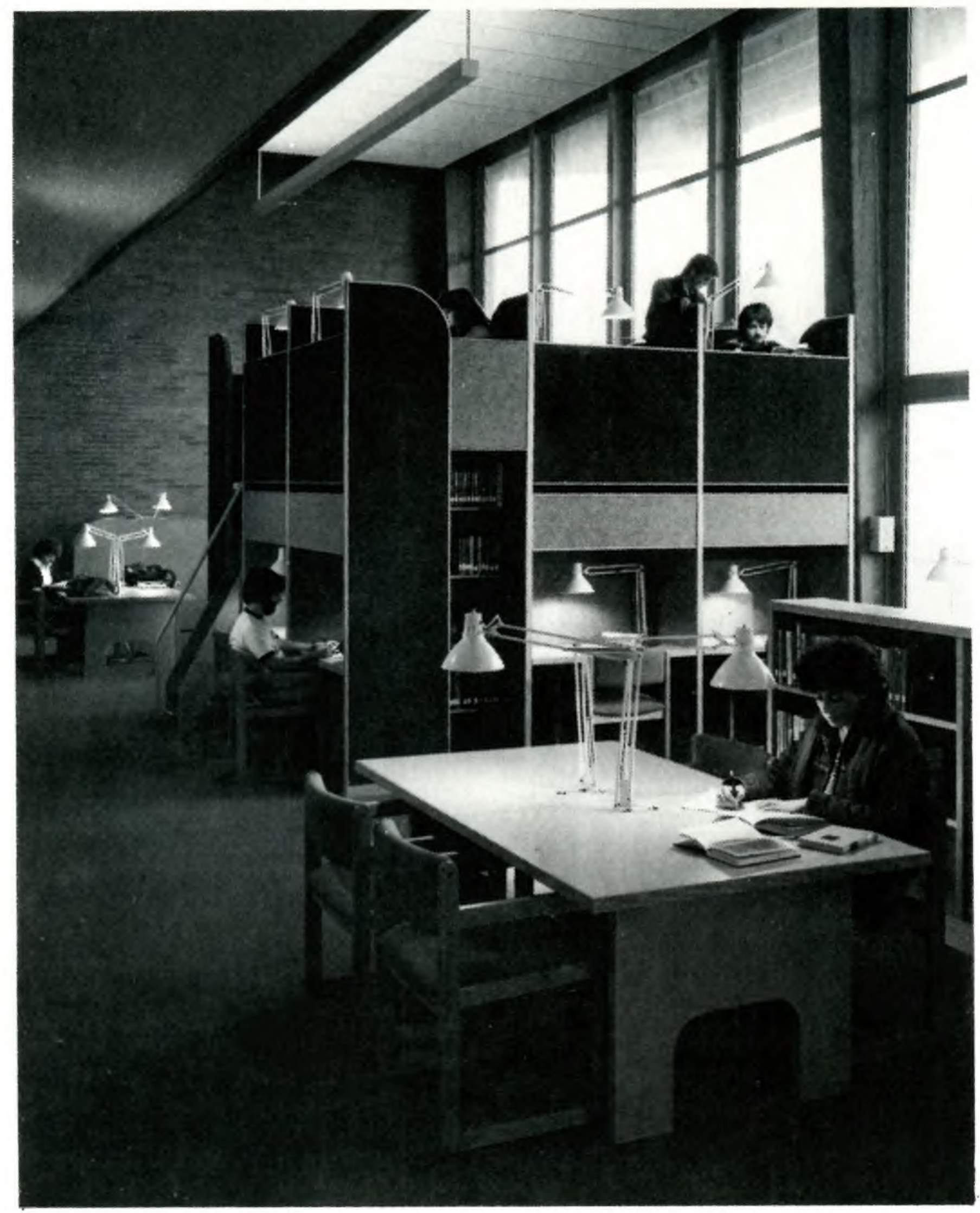

\section{.... a better approach to the use of space}

FOR INFORMATION ON THIS AND OTHER INNOVATIVE FURNITURE, PLEASE WRITE OR CALL

MÖ.

7733 GROSS POINT ROAD P.O. BOX 226 SKOKIE, IL 60076-0226

PHONE (312) 677-0333 TELEX 28-9429 


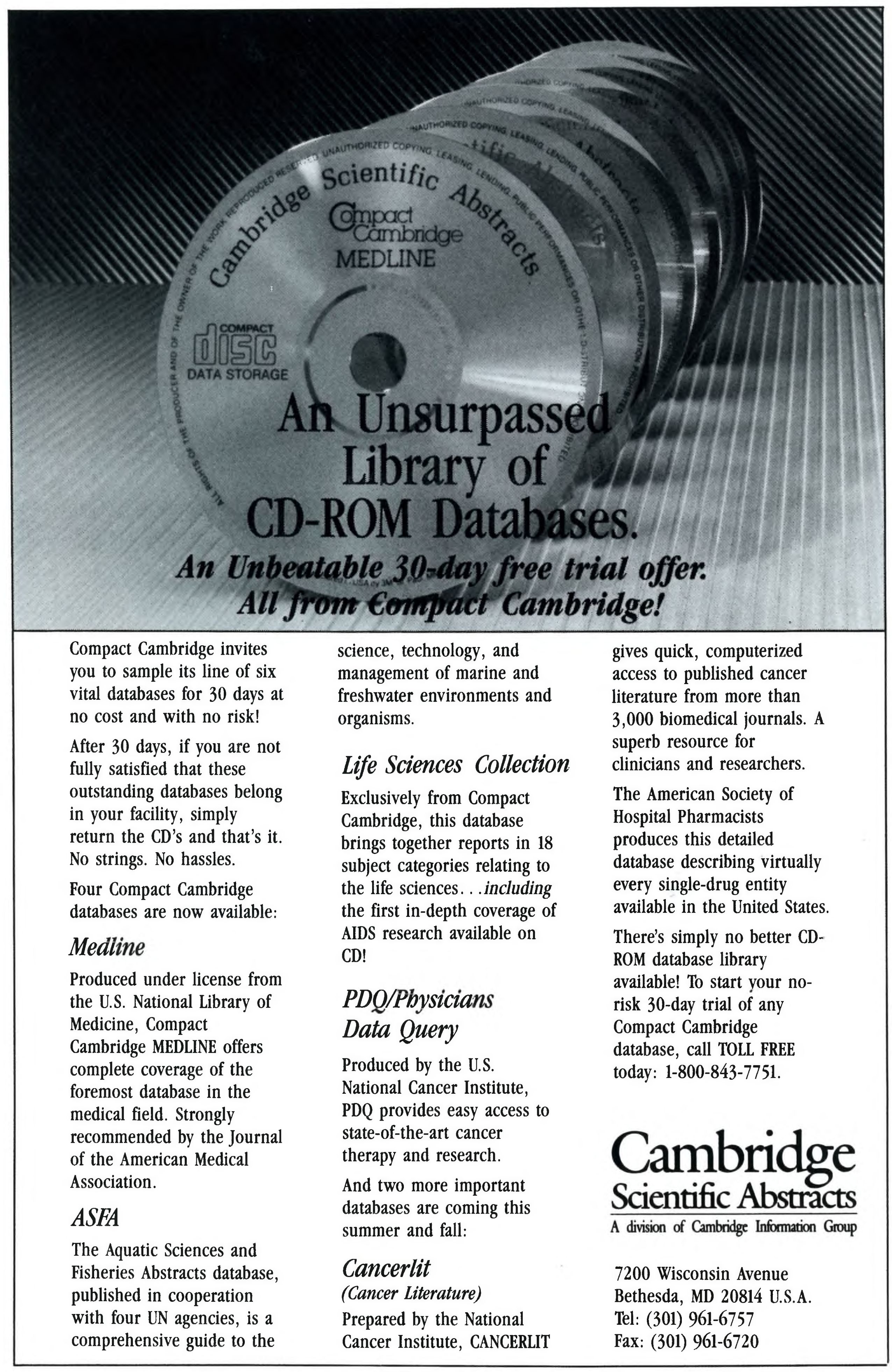

